\title{
HERECKÝ ZJAV MONIKA POTOKÁROVÁ
}

\author{
KAROL MIŠOVIC
}

Ústav divadelnej a filmovej vedy Centra vied o umení Slovenskej akadémie vied, Bratislava

\begin{abstract}
Abstrakt: Monika Potokárová (1992 - 2019) sa počas krátkej profesionálnej kariéry stala protagonistkou mladej hereckej generácie Činohry Slovenského národného divadla. Stvárnila vyše štyridsat rôznorodých rol v réžiách významných slovenských i zahraničných režisérov. Bola nielen autentickou predstavitel'kou tragických hrdiniek z klasického repertoáru, ale plastický talent jej dovoloval kreovat' i postavy v inscenáciách popierajúcich psychologicko-realistické kánony slovenského činoherného herectva. Príspevok sa zaoberá najvýznačnejšími úlohami mladej herečky a snaží sa definovat’ tvárnost', flexibilitu a jedinečnost̉ jej umeleckej osobnosti.

Kl'účové slová: Monika Potokárová, herectvo, Činohra Slovenského národného divadla, Vysoká škola múzických umení, súčasné slovenské divadlo
\end{abstract}

Nie je zvykom písat' herecký portrét umelca, ktorý dosiahol len dvadsat'sedem rokov života. V tomto veku sa iba začína profilovat' herecká osobnost’ i jej osobitost'. Z vitálnych, životaschopných rol, kde ústrednú úlohu zaujíma mladost’ a s ňou súvisiace umelecké vyžarovanie, herec/herečka postupne prechádza k postavám, ktoré jasne poukážu na možnosti jeho/jej umeleckého rozsahu. Bud’ rozvrstvujúcu sa flexibilitu schopnú spiet’ k métam charakterového herectva, alebo uviaznutie v type, čerpajúce výhradne $\mathrm{z}$ fyziognomických predpokladov.

Monika Potokárová (30. 6. 1992 - 25. 11. 2019) bola umelkyňou, ktorá už v úvode kariéry smerovala k prvej zo spomenutých ciest. Žial', jej sl'ubne sa rozvíjajúca kariéra sa predčasne uzavrela dobrovol’ným odchodom zo života. Herečka však už v školských inscenáciách a pri prvých stretnutiach s profesionálnym javiskom dokázala, že jej je cudzie typové zjednodušenie, že kráča k vehementnému pomenovaniu l'udskej obsažnosti a k rolám komplikovaných ženských individualít. V nastupujúcej generácii predstavovala typ, ktorý bol v histórii slovenského herectva zastúpený v takýchto krajných polohách najmä Elenou Zvaríkovou Pappovou, Emíliou Vášáryovou či Božidarou Turzonovovou - nenaivné, zmyslové, efektnou vonkajškovost’ou nesuplované, predčasne vyspelé ženstvo so schopnost’ou intenzívneho citového prežitku, dopíňaného jasne kontúrovaným exteriérovým výrazom.

Monika Potokárová nebola typom prvoplánovej krásky, zaujala skôr špecifickým osobnostným kúzlom. Stredne vysoká subtílna postava, dlhé havranie vlasy, jemné črty tváre, ktorej dominovali plné pery, mierne vystúpené lícne kosti a vel'ké tmavé oči schopné budit’ rešpekt či pôsobit uhrančivo, ale aj evokovat’ plachost’ a bezbrannost' - akoby táto kombinácia telesných danosti predurčovala jej typové zaradenie. Počas kariéry sa takmer nestretávala s postavami kultivovaných a romanticky zasnených dievčat, ktoré by sme pri kategorizovaní podl’a niekdajších hereckých odborov nazvali anštand (z nem. slušné správanie). Skôr bola predstavitel'kou ich parodických podôb alebo priamych charakterových opakov. Jej výrazu bola cudzia harmonizácia, 
aj v postavách nejasnej charakteristiky hladala hlbšie konfliktné súvislosti. Mierila k živelnej prirodzenosti, snahe o nájdenie l’udskej pravdivosti, ktorú tlmočila v širokej psychologickej tvárnosti. Ak si to však žáner vyžadoval, dokázala sa prispôsobit aj scénickej štylizácii, kde vyjadrovacie prostriedky neboli náhodnými súzvukmi, ale ciel’avedomými antiiluzívnymi prvkami.

Režiséri jej zverovali roly excentrických, povahou nejednoznačných, doslova problémových stvorení, ale i nerezignujúcich a aktívnych žien zápasiacich so životnými nástrahami. $\mathrm{V}$ mnohých prípadoch nešlo o typologicky obmedzené figúry, ale o úlohy s hlbokým vnútorným rozmerom. Potokárová sa dokázala prirodzene pohybovat' medzi tragikou i komikou, dominantou jej herectva bol práve sebavedomý balans medzi týmito žánrovými polohami. Pritom jej herecký talent spočíval nielen v dostatočnom emočnom kvociente a schopnosti vystihnút žánrové či druhové ladenie, ale aj v dare intuitívne prispôsobovat predstavovanej role komplexný výraz. Nebola interpretkou, ktorá by filozoficky analyzovala stvárňované postavy, no akoby sa nevedomky riadila myšlienkou nemeckého teoretika začiatku 20. storočia Carla Hagemanna o maske postavy. Teda o prispôsobení celkového výrazového registra „špecifickému spôsobu reči pre figúru, farby zvuku, tvorenia hlások, zdôrazňovania, intelektuálneho a duševného prízvuku, členenia viet a tempa“1. Potokárovej sa totiž vždy darilo nachádzat’ individuálne črty postáv a týmto subjektívnym psychologizmom ich od seba v rámci možností herecky odlišovat'.

Herečka počas ôsmich rokov aktívnej profesionálnej tvorby (t. j. od nástupu na Vysokú školu múzických umení v roku 2012 až po úmrtie v novembri 2019) presvedčila, že patrí k najosobitejším zjavom svojej generácie. Generácie, ktorú vzostup a definitívna príznačnost’ poetiky hereckého umenia ešte len čaká. Potokárová to dokázala v predstihu. Krátky život jej však nedovolil dospiet’ k vyhranenému hereckému štýlu. Preto analýzu jej umeleckého profilu nemožno diferencovat’ spôsobom, aký je pri podobných prácach zaužívaný, t. j. podla dramaturgie postáv, kontinuálnych herecko-režijných spoluprác, žánrového zaradenia úloh, estetiky prejavu či zásadných etáp kariéry. Na priblíženie osobitosti herectva Moniky Potokárovej teda zvolíme chronologickú cestu, od úvodných krokov na školskom javisku až po dobu, ked' sa stala protagonistkou mladej generácie Činohry Slovenského národného divadla.

\section{Prológ tvorby}

Herečkine prvé kontakty s dramatickým umením sa prekvapivo nespájajú s činoherným divadlom. Potokárová disponovala značným muzikálnym a pohybovým nadaním ${ }^{2}$, preto po absolvovaní bratislavského Cirkevného konzervatória v ročníku Anny Javorkovej pokračovala v štúdiu na Katedre neverbálneho divadla Hudobnej a tanečnej fakulty Akadémie múzických umení v Prahe. Počas dvoch semestrov sa učila rozvíjat fyzický prejav ako základné herecké východisko. Ciel'avedome pestovala schopnost' reagovat na zmeny rytmu vnútorného napätia, nenútenost' prudkých

${ }^{1}$ HAGEMANN, C. Herecké umění a herci. Cit. podla RUTTE, M. O uměníhereckém : Kestetice a psychologii divadelní a filmové tvorby. Praha : Jos. R. Vilímek, 1946, s. 156. Preklad z českého jazyka K. M.

${ }^{2}$ Herečkine spevácke kvality využili mnohí režiséri aj v činoherných inscenáciách (Rivers of Babylon, Zo života l'udstva, Kabaret Normalizácia, Vojna a mier, Jób a i.), raz dostala aj príležitost’ sama komponovat’ scénickú hudbu (V̌̌etko za národ). 
obmien, persifláž výrazového registra, ale i zručnost’ prenášat do pohybovej a gestickej akcie impulzy duševných motivácií, a tak dosiahnut emočnú plnost'. To všetko zúročila aj v nasledovnej činohernej kariére: Potokárová totiž dokázala na javisku upútat' i v nenaratívnych momentoch. Cez jednoduchý, na prvý pohlad až samočinný mimický či gestický prejav vedela výstižne pretlmočit informáciu o citovom rozpoložení stvárňovanej úlohy, a pritom neporušit’ atmosféru výstupu či si svojvol'ne uzurpovat herecký priestor. Nedokončené štúdium pantomímy tak malo pre mladú herečku značný prínos.

Po roku strávenom v Prahe, kde nadobudla širšie teoretické, ale najmä praktické základy pantomimického umenia, odchádza do Bratislavy a v školskom roku 2012/2013 nastupuje do prvého ročníka činoherného herectva na Divadelnej fakulte VŠMU, vedeného Martinom Hubom, Michalom Vajdičkom a L'ubošom Kostelným. Huba po prvom semestri školu opúšta a poslucháčov zvyšné roky vedie dvojica Vajdička - Kostelný. Potokárová už na tzv. semestrálnych predvádzačkách, t. j. v etudách formovaných pedagógmi alebo spolužiakmi z odboru réžie, zaujala výsostné postavenie. A to nielen netuctovým zjavom. Už v začiatkoch štúdia dokázala vyjadrił’ maximum vnútorného na minime vonkajškového. Jej rýchlo zrejúce herectvo vycítila aj širšia divadelná obec. Preto od prvého ročníka dostávala ponuky z mimoškolských projektov a počas piatich rokov štúdia hostovala na niekolkých bratislavských kamenných i nezávislých scénach.

Ťažiskom začiatku jej činohernej tvorby však bola práca na školskej pôde. Dve roly, ktoré vytvorila v rámci bakalárskeho ročníka v študentskom Divadle Lab, až príznačne predznamenali okruhy postáv, ktoré bude neskôr stvárňovat najčastejšie. Na jednej strane to bola vášnivá, ale nevydareným životom deprimovaná Máša z Čechovových Troch sestier (14. 1. 2015), následne smutno-smiešny portrét hrdej vlastenky Hany Čepčínskej z dramatizácie Timravinej novely V̌̌etko za národ (21. 4. 2015).

Tri sestry v réžii Jakuba Mudráka nepatrili medzi emblémové diela študentského divadla, inscenácia totiž len ilustratívne dekorovala príbehové linky hry. Vo výkladovo neukotvenej réžii sa mladí herci poväčšine zmietali v prehnane psychologizovaných či naopak, v motivicky nevyjasnených polohách. Koherentnostou výkonov vynikli iba predstavitel'a manželov Kulyginovcov - Marek Koleno a Monika Potokárová. Herečka oblečená do jednoduchých čiernych šiat, ktoré farebne splývali s jej dlhými vlasmi zviazanými do jednoduchého chvosta, predstavovala Mášu ako senzitívne stvorenie, ktorej chýba hrejivý l'udský dotyk aj uznanie osobnostných kvalít. Presne to, čo jej egocentrický, suverénne vystupujúci životný partner nedokázal poskytnút'. Nespokojnost’ a neuspokojenost’ vnútorných túžob urobili z jej Máše ženu v reakciách nervnú, cynickú a k problémom druhých doslova l’ahostajnú. Negativistickú bytost’ zameranú len na l'utovanie samej seba. Až náruživé vzplanutie k Veršininovi bolo po dlhej dobe otupenosti prvým jasným lúčom v pochmúrnom svete tejto inteligentnej ženy, ktorá si dobre uvedomovala nemožnost' zastavit’ vlak, v ktorom sa, ani nevediac ako, ocitla vedl’a narcistického Kulygina. Kritička Katarína Cvečková o interpretácii i kreácii výstižne napísala: „Jej Máša je žena túžiaca po láske - o čo viac neznáša svoj terajší život (...), o to viac sa upne na velitel’a batérie Veršinina (Martin Varínsky). Už od prvého stretnutia prebieha medzi nimi citelné napätie. To sa postupne graduje, ich ,vztah' dostáva kontúry dokonalej romance, ktorej význam Veršinin napokon celkom zneguje odchodom takmer bez rozlúčenia. Najskôr apatická a unudená Máša sa postupne mení na vášnivú a milujúcu, aby napokon skončila 
s ešte väčšou rezignáciou a apatiou. Dvojica predstavitel’ov Máše a Veršinina napokon v inscenácii ponúka aj najzaujímavejšie mizanscény. Za všetky možno spomenút napätím a vášňou nabité zbližovanie za stolom, kde letmé, takmer náhodné dotyky rúk prechádzajú do vzrušeného ,Milujem t’a!' najskôr impulzívneho cez smiech, potom v celkom vážnom tóne. ${ }^{\prime 3}$

Energická Hana zo Všetko za národ tvorila jasné opozitum k nespokojnej a myšlienkami trudnej Máši. Dejotvorným centrom Timravinej novely, dramatizácie Ondreja Šulaja aj inscenácie Matúša Bachynca sú úlohy dvoch slečien - nedávno dospelej Viery Javorčíkovej a starej dievky Hany Čepčínskej. Pre obe našiel Bachynec v ročníku vhodné predstavitel'ky, ktoré hereckým naturelom a v intenciách pôvodnej predlohy tvorili produktívne výrazové antonymá. Kým Monika Horváthová charakterizovala romanticky založenú Vieru cez nenútený až decentný prejav, tak Potokárová tvarovala Hanu s prudkým groteskným nádychom. Už to nebola charizmatická Máša, ale vizuálne nevábna žena v nohaviciach, neforemnej bielej blúzke, s bodkovanou hodvábnou šatkou prehodenou cez plecia, hustou ofinou siahajúcou až k očiam zakrytým vel'kými kruhovitými okuliarmi. Teda žiadna femme fatale, ale osoba budiaca impresiu neprítažlivej učitel'ky, pripravenej za každých okolností vel'kohubo poúčat' najbližšie okolie. Na rozdiel od vždy upravenej Viery, u Hany zaujímal vzhl’ad nepodstatné miesto $\mathrm{v}$ rebríčku osobnostných priorít. Na prvom totiž dominovalo - herečkou vždy freneticky vyslovené - heslo: Všetko za národ.

Potokárová s režisérom sa na horlivú patriotku Hanu pozerali s miernym ironickým nadhladom. Preto sa herečka vo výkone nevyhýbala okázalému pátosu, najmä v momentoch, ked’ agilne burcovala za národnostnú otázku. Tým predstavitel'ka podporila otravnost' Haniných nadnesených rečí. Síce sa prítomných lakonicky pýtala, či ich neobtažuje jej prítomnost', ale v skutočnosti to bola len rečnícka figúra hundravej a v názoroch kategorickej ženy. Pri presadzovaní vlastných vyhranených postojov zachádzala tak d’aleko, že strácala akúkolvek sebareflexiu, mimiku zvíjala do prudkej grimasy, nebála sa použit’ rozhorčené, priam až neženské gesto, v rámci rozhovoru uštipačne predniest’ šovinistickú poznámku či dialogického protivníka doslova prebodnút' odsudzujúcim pohladom. Bachynec s interpretkou budovali formu Haniných vlasteneckých prejavov i jej bokom vyslovených poznámok v tónine narušujúcej atmosféru inak čechovovsky ladenej inscenácie. Preto Potokárová hrala tieto Hanine pasáže s obrovským, nekritickým zanietením a rétorským zveličením, niekedy siahajúcim až do deklamačných póz. V tom spočíval dôvod, prečo jej Hanu nikto z okolia nebral vážne. Pôsobila ako fanatička, ktorá je otravná i smiešna. Kritička Martina Mašlárová v jej výkone dokonca našla výrazovú asociáciu s predošlou predstavitel'kou Hany, Evou Pavlíkovou: „Čepčinská nie nepodobná svojej predchodkyni z Nitry v jej mondénnom výraze a afekte, ktorý však nie je hereckou chybou, ale črtou typickou pre túto pre národ zapálenú agitátorku. “4

Oproti pôvodnej Šulajovej dramatizácii akcentovali mladí tvorcovia aj tému Haninej ženskej prirodzenosti. V Potokárovej podaní nebola iba neúnavnou vlastenkou,

${ }^{3}$ CVEČKOVÁ, K. Nenaplnené túžby troch sestier a jednej inscenácie. In Monitoring divadiel, 26. 4. 2016. [online]. [cit. 29. 7. 2020]. Dostupné na internete: https://www.monitoringdivadiel.sk/recenzie/recenzia/nenaplnene-tuzby-troch-sestier-a-jednej-inscenacie/.

${ }^{4}$ MAŠLÁROVÁ, M. Národ, to znie hlúpo. In Monitoring divadiel, 17. 4. 2016. [online]. [cit. 29. 7. 2020]. Dostupné na internete:: https://www.monitoringdivadiel.sk/recenzie/recenzia/narod-to-znie-hlupo/. 


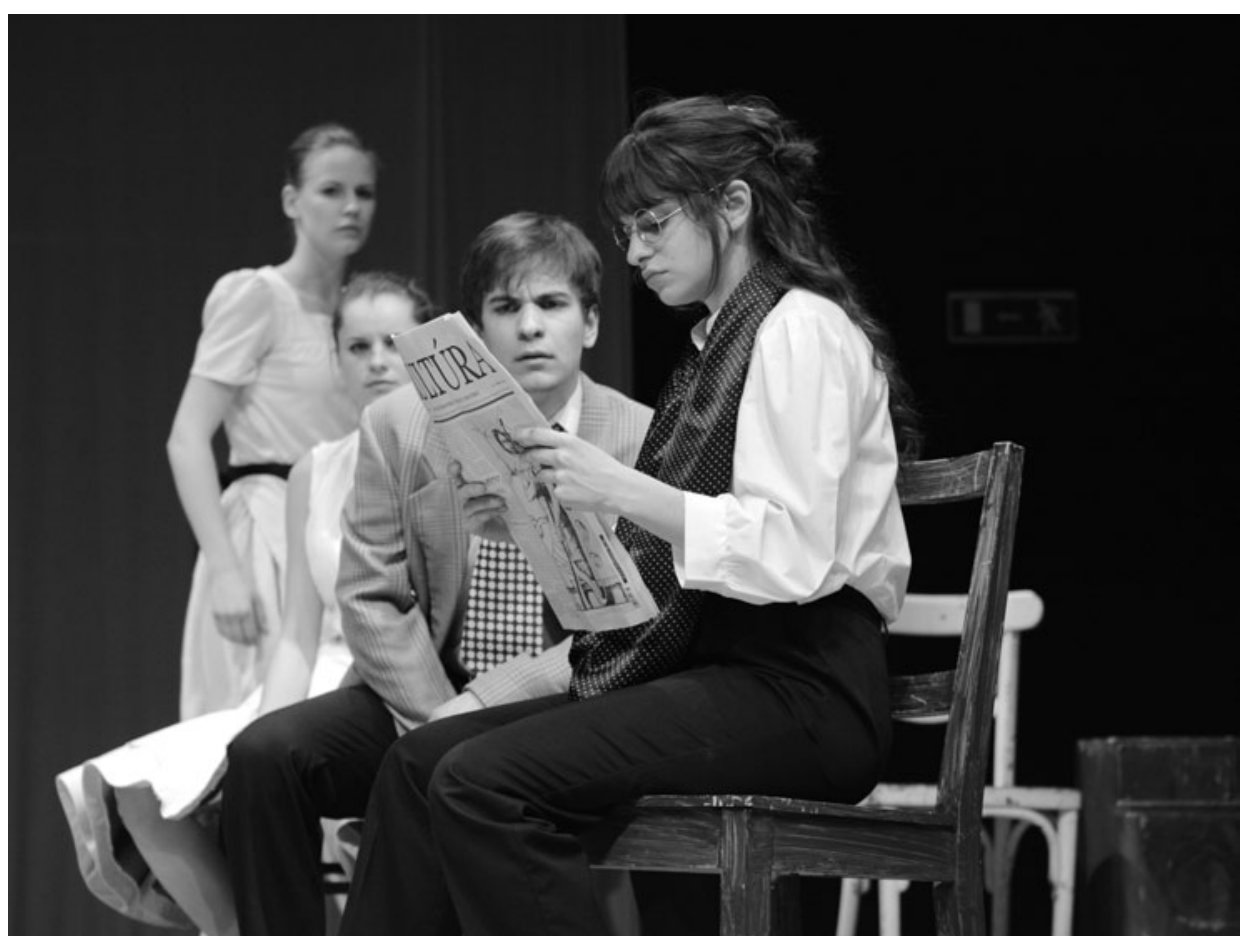

Božena Slančíková Timrava - Ondrej Šulaj: Všetko za národ. Vysoká škola múzických umení, premiéra 21. 4. 2015. Réžia Matúš Bachynec. Barbora Palčíková (Olina), Monika Šagátová (Elena), Marek Koleno (Limbovský), Monika Potokárová (Hana Čepčínska). Foto archív VŠMU. Snímka Radovan Dranga.

a teda komickým oživením ostatných príbehových tokov inscenácie, ale i lúbostne nenaplnenou ženou, ktorá by sa rada obetovala nielen národu, ale aj životnému partnerovi. Potokárová upokojením inak excentrického výrazu neochvejnej národnej buditel'ky upozorňovala prostredníctvom drobných nuáns (mimovolné pohlady, intonačné dížky a pod.) na fakt, že bezvýhradné city k národu nie sú tie jediné, čo hýbu jej dušou. Tie boli nasmerované k Amerikánovi Hagarovi (Samuel Simko), ktorého prítomnost’ spôsobovala tejto urozprávanej ženštine náhlu stratu koncentrácie. No počiatočnú omámenost’ sa vždy úzkostlivo snažila zahovorit’. Unesená jeho mužným slovanským zjavom zasnívane vyslovila: „Krásny.“ Akonáhle si uvedomila, že to povedala nahlas, tak rýchlo, s didaktickým tónom nervóznej kantorky prichytenej pri niečom, čo sa nesnúbi s jej reputáciou, doplnila: „Krásny vzor človeka!“”. Pátosom chcela prekryt’ rýdzi cit, ukrývajúci sa pod neochvejným rodol’ubstvom.

\section{Vstup na profesionálnu scénu}

Súpis Potokárovej tvorby na školskom javisku počas magisterského stupňa doplnili ešte dve postavy v réžii Matúša Bachynca - Anči, povedané názvom slávnej hry Jeana Paula Sartra počestná pobehlica, zo sociálnej drámy Františka Langera Periféria (26. 11. 2015) a služobná Šue v plocho moralistickej inscenácii Je svätá (16. 5. 2016), 
adaptujúcej novelu Mira Gavrana o biblickej Judite. V poslednom ročníku naštudovala Potokárová len dve okrajové úlohy v inscenácii troch aktoviek Woodyho Allena Urbánny sexualizmus (21. 11. 2016) v pedagogickej réžii Romana Poláka. Nieže by ju študenti réžie obchádzali, ale v tomto čase už bola nanajvýš vytaženou členkou Činohry SND.

Jej prijatie do angažmánu národnej scény znamenalo logické vyústenie niekol'koročnej spolupráce. Už počas prvých ročníkov tu so spolužiakmi hostovali v komparzových úlohách v Littelových Láskavých bohyniach (2. 4. 2014) či v Švantnerovej Neveste hôl' (31. 1. 2015). Postupne na seba čoraz výraznejšie upozorňovala a režiséri jej následne pridelovali aj náročnejšie a rozsahom väčšie party, v ktorých mala možnost’ prejavit’ prvé náznaky budúceho charakterizačného umenia. Či už to boli Božím proroctvom predchnutá Kristína v životopisnej epopeji o učitel’ovi národov Labyrinty a raje Jána Amosa (9. 6. 2015), či skôr dekoračná než tvárnym dramatickým konfliktom osnovaná rola Jany v kompozícii aktoviek tria autorov a v réžii tria generačne spätých režisérov Morálka 2000+ (2. 4. 2016), alebo nadmerne prostoduchá Mary Vetserová, milenka princa Rudolfa II. z hry Viliama Klimáčka Sissi. Úteky Alžbety Rakúskej (7. 6. 2016). A hoci ani jedna $\mathrm{z}$ menovaných rol nepatrila $\mathrm{k}$ vd’ačným príležitostiam, kde by mohla naplno prejavit hereckú invenciu, Roman Polák po premiére Morálky 2000+ ponúkol poslucháčke vtedy len štvrtého ročníka angažmán v Činohre SND. Bola to jeho vel'ká odvaha, ale i presvedčenie o d’alšom vývine potenciálu mladej umelkyne. A pre Potokárovú vel'ký záväzok.

Treba zdôraznit', že riaditel' Činohry SND Polák poznal herečku už zo školských projektov, kde mohol ako pedagóg jej spolužiakov režisérov sledovat’ Potokárovej postupne sa rozvíjajúce umenie. Súčasne netreba zabúdat', že v období, ked' dostala príležitost' stat' sa členkou národného divadla, mala popri vyššie spomenutých úlohách v repertoári aj d’alšiu, pri ktorej dostatočne poukázala na svoj talent: Lenku v dramatizácii prózy Petra Pištanka Rivers of Babylon (30. 1. 2016). Potokárovú na spoluprácu oslovil Slovinec Diego de Brea, v slovenskom kontexte známy réžiami kontroverzne prijatých inscenácií Shakespearovho Coriolana (15. 4. 2011) a Brechtovej Malomeštiakovej svadby (9. 2. 2013), uvedených vo Vel'kej sále Činohry SND. Vlastnú dramatizáciu kultového slovenského románu naštudoval v Štúdiu SND, teda v priestore, ktorý jeho zvrchovane expresívnej a na hereckých detailoch založenej režisérskej letore vyhovoval adekvátnejšie než monumentálne javisko.

Kým predošlé de Breove inscenácie rozvírili širokú diskusiu odborného i laického publika, tak transkripcia prozaickej predlohy o vzostupe novej vládnucej triedy po roku 1989 bola takmer unisono prijatá ako jeden z najúspešnejších príspevkov do prebiehajúcej divadelnej sezóny. Komorný štúdiový priestor s industriálne pôsobiacim vizuálom vhodne korešpondoval s mysterióznostou príbehu zasadeného do hotelovej kotolne, aj s univerzálnym časovým zaradením de Breovej inscenácie. Ako výstižne podotkla Soňa J. Smolková5: „Jazyk jeho úpravy je obnažený na kost', stroho ide po podstate deja (...). Dramatizácia je aj napriek výrazným skratkám plne funkčná a zachováva čaro Pištankovho jazyka. Postavy o sebe často hovoria v tretej osobe a nechýba ani autentický štavnatý slovník podsvetia. ${ }^{\text {“6 }}$

\footnotetext{
${ }^{5}$ Autorka publikujúca pod menom Soňa Smolková, Soňa J. Smolková a Soňa Jánošová.

${ }^{6}$ SMOLKOVÁ, S. J. Brehy babylonských riek sú tmavé a neveselé. In Pravda, 2016, roč. 26, č. 26, s. 32, 2. 2. 2016.
} 


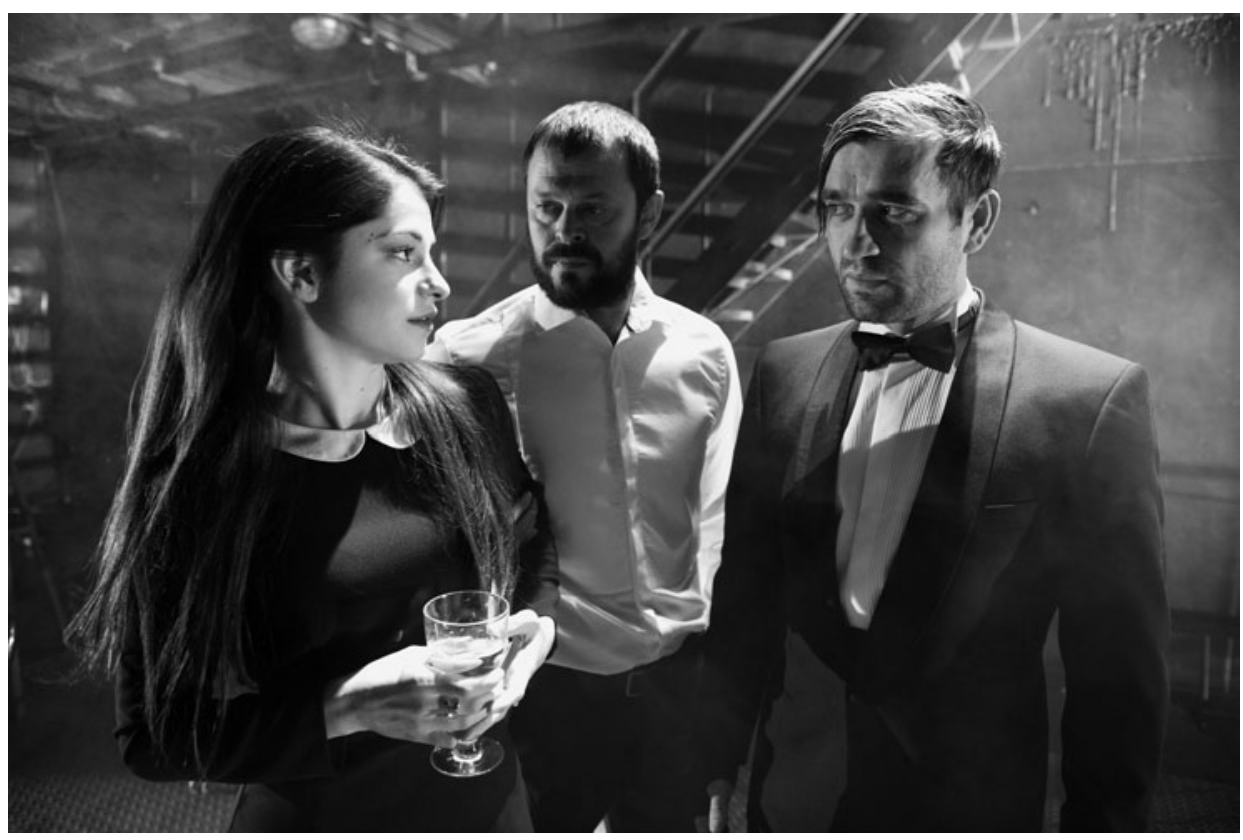

Peter Pištanek - Diego de Brea: Rivers of Babylon. Činohra Slovenského národného divadla, premiéra 30. 1. 2016. Réžia Diego de Brea. Monika Potokárová (Lenka), Alexander Bárta (Video-Urban), Milan Ondrík (Rácz). Foto archív SND. Snímka Martin Geišberg.

Dominantou inscenácie boli najmä koncentrované a režisérovu poetiku naplno rešpektujúce herecké výkony Milana Ondríka, Petry Vajdovej, Diany Mórovej, Roberta Rotha, ale i začínajúcej Moniky Potokárovej. Tá stvárnila nevel'kú rolu Lenky, ktorá sa objavuje v príbehu až v jeho poslednej tretine, ale pre d’alší vývoj má smerodajný význam. Herečka vošla na scénu v čiernych, po kolená siahajúcich šatách s bielym golierom, akoby si odskočila z katolíckeho penzionátu. So živočíšnym Ondríkovým Ráczom spočiatku komunikovala prostým, nevinným hlasom a v očiach sa jej dali zachytit’ obavy, no i fascinácia maskulínnym, arogantným mužom, s akým ešte v živote nemala dočinenia. Pri ich nasledujúcom stretnutí sa už nebála spontánnejšie uvol'nit’ úsmev, aj premenit hlasovú melodiku ostychu a nejasnej formulácie, rozvinúc ju do prívetivejšej, harmonickejšej polohy. Stále si však od Rácza udržovala rezervovaný odstup. Ked’ pochopila, že cudnost' je to jediné, čo si on neželá, úzkostlivo a s badatel’ným strachom v hlase ho žiadala, aby ",to“ nerobil. No on jej ruku položil na lono, naddvihol ju a oprel o medený plech, ktorý v inscenácii predstavoval znak intímneho zblíženia žien s vedúcim kotolne. Pri jej tretom vstupe na javisko to už bola úplne iná Lenka: sebavedomo kráčajúca domina v svadobných šatách, s umelo naškrobeným úsmevom, z ktorej vyprchala predošlá dievčenská plachost’ a kultivovanost'. Mali sme čest’ s nastávajúcou pani Ráczovou, a to nielen v zmysle plánovaného úradného zväzku, ale najmä nečakanou synergiou ich dovtedy odstredivých naturelov. Z Lenkinho pohŕdavého a pevného tónu reči sa dalo odčítat', že už so samozrejmostou prijala úlohu prvej dámy podsvetia a stotožnila sa s métami budúceho manžela. Záver Rivers of Babylon pointovala jej postava spevom skladby Wonderful Life. „Aj vd’aka 
piesni sa inscenácia končí prekvapivým pocitom happy endu“" , skonštatovala Soňa J. Smolková. No nie pre každého. Pieseň, ktorá v reprodukovanej podobe znela počas celej inscenácie, vytvárajúc jej hudobno-tematický lajtmotív, Potokárová tlmočila tak, že jej „(...) sentimentálna interpretácia naznačuje, že nádherný život, o ktorom spieva, je určený len niekol’kým vyvoleným“8.

\section{Herečka poetka}

Potokárovej ortoepické dispozície i zmysel pre melodickost’ až hudobnost’ slova ju predurčovali k umeleckému prednesu. Mala nižšie posadený hlas, alt bohatej farebnej škály i dramatického rozpätia, ktorým dokázala v emočnej plnosti pomenovat' širokú paletu citových nuáns, od tragického vzopätia až po bezbranný romantizujúci podtón. Pri recitácii vedela vystihnút rytmické hodnoty verša, požiadavky prízvuku, dížok, tempa i páuz. Preto nemožno opomenút jej aktivitu v oblasti divadla poézie, ktorá tvorí významnú súčast' jej tvorby. ${ }^{9}$

Už v prvom ročníku VŠMU ju jej bývalý pedagóg z konzervatória Peter Weinciller oslovil na spoluprácu pri inscenácii Ó sláva hviezd ó sláva (20.12. 2012) a aj dve nasledujúce Potokárovej úlohy v profesionálnom divadle boli zviazané s prednesom. V novom hracom priestore SND, Modrom salóne, účinkovala v projektoch Daniela Heviera - Večer rockovej poézie (26. 6. 2013) a Blake is black (22. 10. 2013). Kým tieto inscenácie zlyhávali na slabej invenčnosti obsahu i formy, tak Weincillerova kompilácia troch Hviezdoslavových balád poukázala na možnosti modernej interpretácie klasickej poézie. Margita, Zuzka Majerovie a Anča sa vd’aka živej l’udovej hudbe, kvalitnému spevu aktérok a najmä rozčleneniu textov do dynamických a herecky vd’ačných dialógov pretavili do pútavej javiskovej podoby. Tej dominovali tri herečky - Nora Ibsenová, Barbora Palčíková a Monika Potokárová. Všetky tri uplatnili vysokú techniku kultúry slova v súzvuku s herectvom hyperboly, skratky i akcelerácie prostriedkov, vynikajúc tak v lyricky jemných odtieňoch, ako aj v hlasovo pevne nasadených parodických strihoch. Inscenácia si po premiére získala v kultúrnych kruhoch značnú popularitu, pričom recenzenti jednoznačne vyzdvihovali práve Potokárovej výkon, organicky v sebe miesiaci groteskný nadhl'ad s bezprostrednou rurálnostou a rapsodickými spodnými prúdmi: „Nevšedným a azda i najväčším prekvapením bol (...) výkon Moniky Potokárovej, ktorej doménou bolo striedanie prežívania a odstupu, čím do inscenácie vniesla žiaduci ,realistický' humor. " ${ }^{10}$

Pokračovaním snahy o renesanciu divadla poézie v súčasnom divadelnom priestore bola aj inscenácia Kataríny Šafaříkovej, pedagogičky prednesu na VŠMU. Tá spolu so študentkami Monikou Potokárovou a Annou Rakovskou vybrala ukážky z tvorby slovenských poetiek Mily Haugovej, Kataríny Kucbelovej a Tatjany Lehenovej, ktoré vo vlastnom hereckom podaní uviedli v Modrom salóne SND pod názvom Branné cvičenie (29. 6. 2016). Úspech scénickej miniatúry spočíval najmä v konvenciou

\footnotetext{
${ }^{7}$ Tamže.

${ }^{8}$ MAŠLÁROVÁ, M. Plávat’ a neutopit sa v špine Babylonských riek. In kød, 2016, roč. 10, č. 4, s. 23.

${ }^{9}$ Potokárová sa počas stredoškolského štúdia niekol'kokrát zúčastnila sútažnej prehliadky Podebradské dni poézie, kde jej recitácia pravidelne získavala ocenenia. Viac pozri http://slovoahlas.cz/pdp/51/data/ PDP_25-04_kor_7.pdf.

${ }^{10}$ PAŠUTHOVÁ, Z. Oslava Hviezd(oslava). In Katolícke noviny, 2013, roč. 128, č. 18, s. 21, 5. 5. 2013.
} 


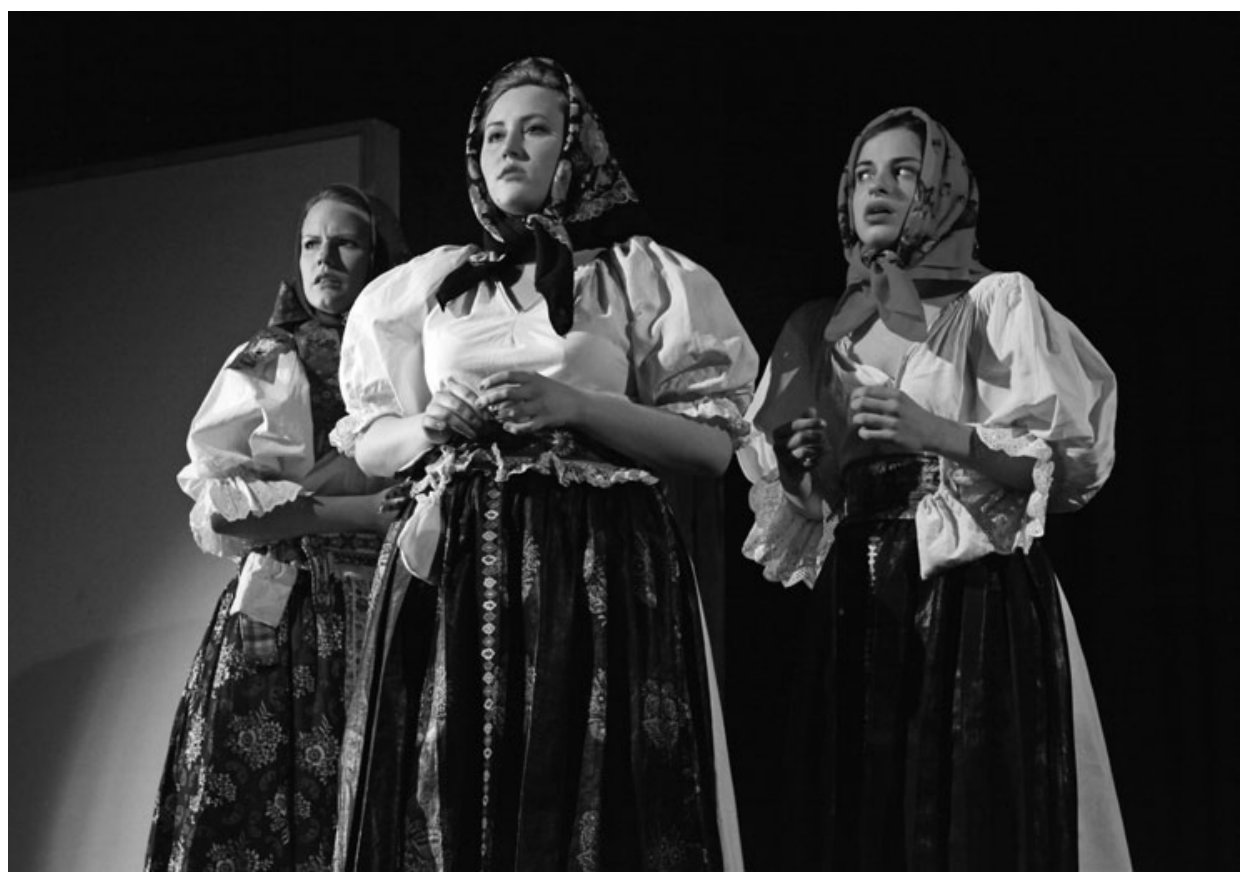

Pavol Országh Hviezdoslav - Peter Weinciller: Ó sláva hviezd ó sláva. Teatro Colorato, premiéra 20. 12. 2012. Réžia Peter Weinciller. Barbora Palčíková, Nora Ibsenová, Monika Potokárová. Foto archív Petra Weincillera. Snímka Michal Lašut.

nezataženom spôsobe tlmočenia textov, ktorý vo svojej recenzii pomenovala aj Soňa Smolková: „Žiadna nedel’ná chvíl'ka poézie, plaché úsmevy a strnulá póza. Ich interpretácia je moderná, prirodzená a spojená s javiskovým konaním. Herečky (...) predvádzajú hravé, neraz bizarné mizanscény, ktoré ilustrujú alebo vtipne dopĺňajú obsah básní. Výrazná je pritom pohybová spolupráca Zuzany Sehnalovej, vd’aka ktorej je ich pohyb presný, neraz synchronizovaný, no najmä presne odrážajúci význam. "11

Herečka svoj mierne zastretý, ale farebne pestrý, emočne variabilný a s l’ahkostou kadencie nesený hlas umelecky využívala aj mimo javiska a kamier. Napríklad nadabovala hlavnú hrdinku v animovanej rozprávke Vajana (2016), kde popri citlivom rečovom nuansovaní zvládla i technicky náročné spevácke party. Výhradne cez verbálny prejav vytvorila tiež titulnú postavu v rozhlasovej verzii Stodolovej Maríny Havranovej (2018), v ktorej civilnými hlasovými prostriedkami, sústrednými tak na charakterizačný detail ako i situačné jednotlivosti, formulovala životný osud mladej ženy, hrdo sa hlásiacej k ideálom slovenských dobrovolníckych výprav meruôsmych rokov.

\footnotetext{
${ }^{11}$ SMOLKOVÁ, S. J. Poetické prekvapenie v Modrom salóne. In Pravda, 2016, roč. 26, č. 220, s. 33, 22.9.
} 2016. 


\section{Členka Činohry SND}

Významný český kritik a teoretik minulého storočia Miroslav Rutte vo svojom prelomovom diele O umění hereckém (1946) napísal: „Pri premene človeka napísaného v človeka trojrozmerného ostáva teda dostatok miesta pre hercovu aktivitu, pre uplatnenie vlastnej kreatívnej osobnosti a intuície, hoci aj v smerniciach, štýle, rytme dopredu určených dramatikom. Herec dostáva od autora duševný obrys postavy a jej osudový rytmus, ale na ňom záleží, aby podla tejto duševnej schémy stvoril skutočného človeka, aby k rytmu osudovému našiel súrodý výraz telesný. (...) Ak maliar smeruje od fyzického k psychickému, tak herec naopak, od psychického k fyzickému. "12 Ale čo ak interpret dostane od dramatika postavu nedohotovenú? Rolu, ktorej chýba potrebná psychická i fyzická motivická podpora, aby ju herec pretavil do životne presvedčivého tvaru?

V repertoári Činohry SND počas Polákovho vedenia oproti predchádzajúcim dvom dekádam enormne narástol počet inscenácií pôvodných slovenských drám. Sezóna 2016/2017 bola dokonca dramaturgicky zameraná výhradne na uvádzanie súčasných hier, s princípom, že slovenskú drámu naštuduje zahraničný režisér a inonárodný text tuzemský tvorca. $Z$ tohto duelu vyšla úspešnejšie druhá kombinácia. Inonárodní režiséri Dino Mustafić (Srbsko), Tillman Köhler (Nemecko) a Vladimír Serre (Francúzsko) totiž inscenovali tituly, ktoré zlyhávali na nesúrodých textových kvalitách. U tria menovaných režisérov dostala hereckú príležitost’ i najmladšia členka súboru Monika Potokárová. Spolupráce so zahraničnými tvorcami boli pre ňu inšpiratívnym pohl'adom na spôsob - povedané Ruttem - premeny prerodu od psychického $\mathrm{k}$ fyzickému, ale vo všetkých troch prípadoch režisérov i herečku obmedzila tézovitost' dramatických noviniek.

V hre Pavla Weissa Zo života l’udstva (5. 11. 2016), ktorá sa stala i témou Potokárovej diplomovej práce, stvárnila rolu devätnástročnej Moniky, naivného dievčata vychovaného ulicou a žijúceho s matkou alkoholičkou na okraji spoločnosti. Monika po náhodnom stretnutí s manipulatívnym partnerom, do ktorého sa fatálne zamiluje, začne klesat’ ešte hlbšie a vzdáva sa aj tých posledných morálnych hodnôt, čo vyústi do jej tragického konca. V inscenácii hry Valérie Schulczovej a Romana Olekšáka Rodáci (3. 6. 2017), kde armáda z neznámych príčin uzavrie do telocvične sociologicky pestrú skupinu civilného obyvatel’stva. zase vytvorila Dominiku trápiacu sa v nefunkčnom vzt’ahu s poval’ačom Dotkom. Weiss, Schulczová i Olekšák preukázali zmysel pre funkčný dramatický efekt, ale pretavili ho v príliš zjednodušujúcej podobe. Vo svojich viac seriálovo akčných než divadelne účinných textoch sa snažili pomenovat’ spoločensko-politickú problematiku súčasného Slovenska, ale premrštený počet tém a fragmentárnost̉ ich stvárnenia pôsobili v divadelných celkoch kontraproduktívne. Účinkujúcim tak pri tvorbe chýbala možnost’ opriet’ sa o presvedčivejšie skomponované postavy. Potokárová hrala v oboch príbehoch exaltované roly, ale k takým extrémnym emočným procesom, akými autori viedli jej Moniku i Dominiku, chýbali jasnejšie dramatické línie. Musela sa teda spol'ahnút výhradne na svoju základnú výrazovú škálu. Síce sa jej podarilo kreovat úlohy „(...)

${ }^{12}$ RUTTE, M. O umění hereckém : K estetice a psychologii divadelní a filmové tvorby, s. 11 - 12. Preklad z českého jazyka K. M. 
bez hereckého pátosu a akéhokol’vek klišé ${ }^{\prime 13}$, ale charakter hier jej zabránil v sebavedomejších výkonoch.

Podobne aj dráma Viliama Klimáčka Zjavenie alebo Hrobárova dcéra (4. 11. 2017) je textom viac naznačujúcim než konkretizujúcim. Autor v ňom zobrazil aktuálnu tému postojov našej národnej mentality k otázke migrácie. Cez kvarteto postáv žijúcich v slovenskom stereotype sprostredkoval štyri odlišné pohl'ady na daný problém. Potokárová stvárnila v hre pasívnu čast’ rodiny, prostoduchú dcéru Gabiku, čoraz častejšie upadajúcu do transcendentálnych záchvatov, v ktorých stretáva biblický pár, Máriu a Jozefa. Teatrológ Miro Zwiefelhofer o postave Gabiky s otvorenostou napísal: „Nebyt' (...) zjavení, jej najzásadnejšou životnou víziou by pravdepodobne zostala úloha vziat’ si za manžela prvého miestneho mládenca, prežit pri ňom zvyšok života a porodit’ mu čo najviac detí. Táto základná typológia by v princípe nemusela byt' zlým východiskovým bodom, lenže ona je zároveň aj tým konečným, a to už problém je. Text sa nesnaží hlbšie hl'adat či analyzovat' príčiny stavu, v akom sa postavy nachádzajú. Jednoducho konštatuje. "14

Potokárová sa teda opät musela vyrovnat’ s jednostrunne napísanou rolou. Výraz aj tentoraz orientovala na tóninu nenútenosti, ked’ prejav zbytočne nepreexponovala a ani dramaticky excentrické pasáže nenasmerovala k okázalému afektu. Možno i preto jej výkon Zwiefelhofer označil za „(na jej pomery) až šokujúco nevýrazný“. ${ }^{15}$ V tom však možno kritikovi oponovat. Herečka sa v naturalisticky ladenej inscenácii usilovala aj v tézovitých replikách nájst' umelecké vyjadrenie blízke k životnej rutine. Nešlo však o nábehy k bezpohlavnej ilustrácii, ale o snahu v emočne konkretizujúcej polohe vymodelovat' obraz obyčajného -nást'ročného dievčat’a, ocitajúceho sa $\mathrm{v}$ takýchto citových i príbehových peripetiách. Preto sa jej herecká umiernenost', ktorou len rešpektovala režijnú koncepciu, mohla javit’ na prvý pohl'ad nevýraznou.

Inscenácia Zjavenia síce tematicky zapadala do Polákovho dramaturgického programu súčasných drám, ale vyskytla sa až v tzv. sezóne svetovej klasiky. Tam popri časom i desiatkami divadelných generácií overených drámach Sofokla, Shakespeara, Ibsena či Hauptmanna pôsobila nanajvýš heterogénne. Nielen obdobím vzniku, ale najmä kvalitou textu. Podobné slová by sa dali vyriect’ aj v súvislosti s o mesiac neskoršou premiérou autorskej inscenácie Kabaret normalizácia alebo Modlitba pre Martu (7. 12. 2017), uvedenej v Modrom salóne SND v rámci off projektov vybočujúcich z monotematických dramaturgických línií. Režisér a autor textu Matúš Bachynec sa týmto dielom rozhodol vzdat' hold komunistickým režimom proskribovanej speváčke a disidentke Marte Kubišovej. V trojčlennom obsadení logicky dominovala jej herecká predstavitel'ka - Monika Potokárová, pre ktorú Bachynec hru napísal. Samotná herečka hovorila o role ako o svojej oblúbenej, no napriek tomu nemožno obíst’ fakt, že sa text ani inscenácia nevyhli nedostatkom spomenutým už pri predošlých pôvodných dramatických novinkách. Kabaret normalizácia ostal v rovine enumeratívneho prerozprávania biografie významnej osobnosti, bez dramatickej plastickosti a podstatnejšej režijnej nadstavby. Slovami Soni Jánošovej: „Škoda (...), že inscenovaný životopis s pesničkami nenechal skutočne zazniet’ aj vážnejšie a temnejšie tóny, ktoré

\footnotetext{
${ }^{13}$ SMOLKOVÁ, S. Zo života l’udstva je polovičný zážitok. In Pravda, 2016, roč. 26, č. 258, s. 31, 7. 11. 2016.

${ }^{14}$ ZWIEFELHOFER, M. Príliš plytké mystérium. In kød, 2017, roč. 11, č. 10, s. 14.

${ }^{15}$ Tamže.
} 


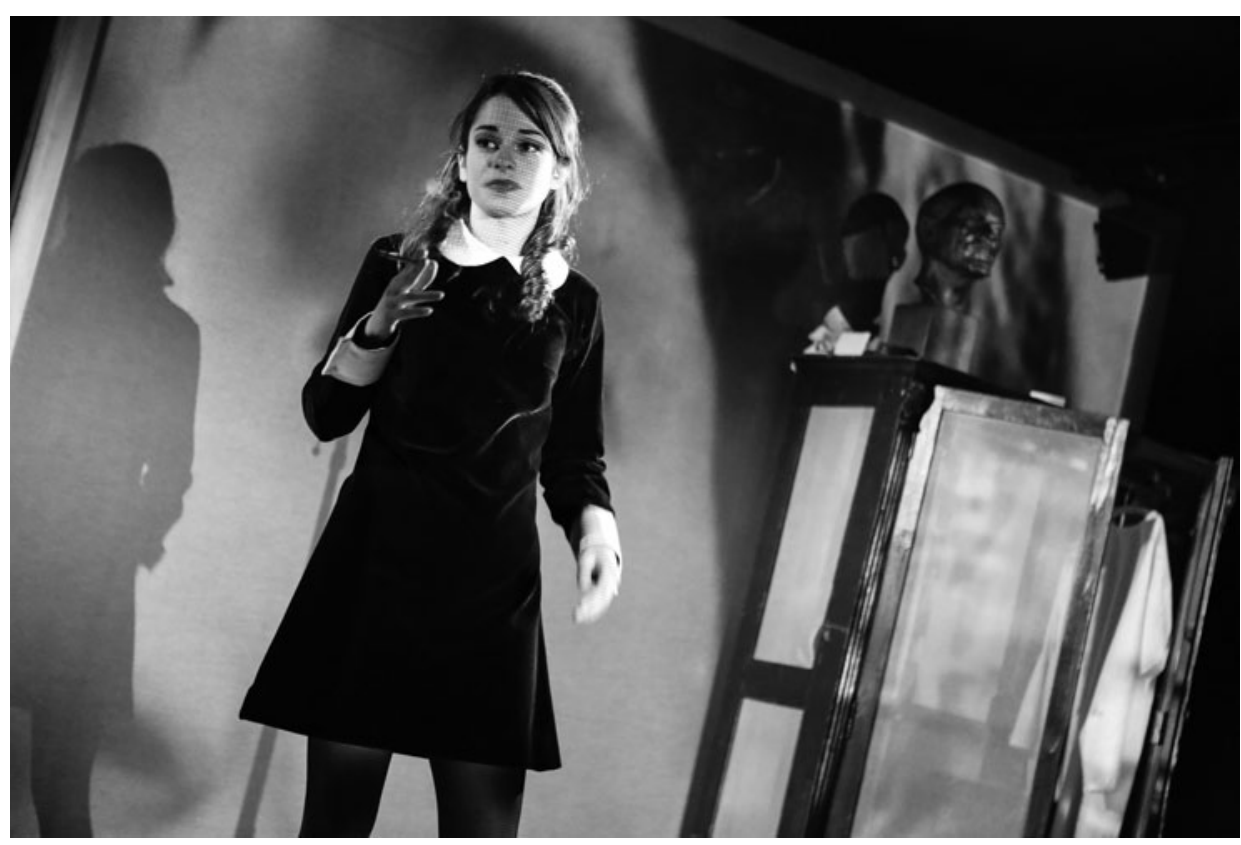

Matúš Bachynec: Kabaret normalizácia alebo Modlitba pre Martu. Činohra Slovenského národného divadla, premiéra 7. 12. 2017. Réžia Matúš Bachynec. Monika Potokárová (Marta Kubišová). Foto archív SND. Snímka Jozef Barinka.

normalizácia prinášala. “16 Potokárovej však ani encyklopedická šablónovitost’ textu nebránila vo výstavbe tvárnej herecko-speváckej kreácie. Napriek tomu, že Bachyncovou ambíciou nebolo vytvorit klasickú dramatickú postavu s vývojovým oblúkom, interpretke sa bez očividných problémov podarilo stvárnit’ osobnostný prerod speváčky „l'ahtikársky“ si budujúcej kariéru v ženu s uvedomelým občianskym postojom.

Potokárovej Kubišová vnímala publikum v komornom priestore ako partnera, ktorému sa po celú dobu inscenácie $\mathrm{v}$ priatel'skom tóne prihovárala, aby mu v chronologickom slede predstavila závažné medzníky svojho turbulentného života. S rovnakou nevtieravostou vstupovala i do dialógov s partnermi. Kritička Lucia Šmatláková jej koncepciu postavy priblížila: „Na jednej strane divákom vecne objasňuje udalosti zo speváčkinho života, no zároveň dokáže autenticky zobrazit’ jej komplexný charakter. Je drsná a priama, ale aj nežná a citlivá. Najvýraznejšie emócie Potokárová prejavuje v piesňach, ktoré dokáže predniest’ suverénne a s technickou l'ahkostou. Modlitba pre Martu tak aj v jej podaní vyznieva dostatočne sugestívne a naliehavo otvára dodnes aktuálnu tému l’udského práva na život v mieri. “" Herečka sa úspešne vyrovnala i s faktom, že stvárňuje skutočnú (ešte žijúcu) osobnost’ našej kultúrnej sféry. Nekopírovala pritom predobraz postavy, neimitovala jej gestické,

${ }^{16}$ JÁNOŠOVA, S. Modlitba pre Moniku, kabaret pre normalizáciu. In kød, 2018, roč. 12, č. 2, s. 50.

${ }_{17}$ ŠMATLÁKOVÁ, L. Ako mocných vystrašila jedna (ne)obyčajná pieseň. In Mloki, 30. 12. 2017. [online]. [cit. 29. 7. 2020]. Dostupné na internete: https://www.mloki.sk/node/819\#/0. 
mimické či spevácke výrazivo, vytvorila autonómnu podobu Kubišovej. Realitu teda neilustrovala, ale účinne interpretovala. Podobne to bolo pri speváckych vstupoch. Snaha výrazovo definovat’ jedinečnost’ Kubišovej speváckeho štýlu sa vzácne snúbila s Potokárovej vlastným speváckym prejavom v konzistentný celok, ktorý zhodnotila kritička Lubica Krénová: „Nemá až taký uhrančivý a sýty hlas ako česká speváčka, ale úctyhodne sa približuje k jeho farbe i híbkam. Jej osud napĺn̆a s dievčenskou úprimnostou, ženskou krehkostou, l'udskou odhodlanost’ou, ale i neschopnost’ou odhadnút dôsledky situácií, do ktorých sa svojimi spontánnymi postojmi dostane. " 18 Potokárová teda opät’ presvedčila o nezvyčajných umeleckých kvalitách, ktoré, ako upozornili kritici, predstihli úroveň samotného textu i réžie.

Rola Marty Kubišovej bolo jednoznačným vítazstvom rýchlo sa etablujúcej herečky, čo potvrdilo aj Divadelné ocenenie sezóny DOSKY 2018 v kategórii Mimoriadny počin v oblasti činoherného divadla za spevácky výkon. No Kabaret normalizácia sa spolu so Zjavením vyskytli v sezóne, ktorú Roman Polák vyhradil pre drámy z okruhu svetovej klasiky, preto Klimáčkov a Bachyncov text nemohli konkurovat’ rokmi osvedčeným titulom, ani poskytnút Potokárovej také herecké príležitosti ako úlohy, s ktorými sa stretla v druhej časti sezóny. Krátko po sebe dostala totiž možnost’ spolupracovat’ s tromi súčasnými klúčovými domácim režisérmi a zároveň účinkovat’ $\mathrm{v}$ dielach troch poetikou diferentných autorov s tromi rozdielnymi pohl'admi na tému ženského hrdinstva. Postupne tak kreovala neštastne zamilovanú Theu z Ibsenovej Heddy Gablerovej (3. 2. 2018), titulnú hrdinku Sofoklovej Antigony (14. 4. 2018) a prudkou životnou kataklizmou prechádzajúcu Natašu z Tolstého Vojny a mieru (9. 6. 2018).

Z tria inscenácií v divadelnej obci najmenej rezonovalo Polákovo naštudovanie Ibsenovej sociálno-kritickej drámy. Režisér preniesol príbeh zo záveru 19. storočia do moderného sveta. Z meštiackeho salóna sa stal súčasný minimalistický bytový interiér, ktorý v základných súradniciach pripomínal výtvarné riešenie z berlínskej inscenácie totožnej hry v réžii Thomasa Ostermeiera, vnášajúceho do súčasného divadelníctva priekopnícky pohl'ad na Ibsenovo dielo. Inšpirácia nemeckým režisérom bola u Poláka badatel'ná vo vonkajšej implikácii prostriedkov tzv. nového realizmu, menej už v dôslednosti vedenia hereckých predstavitel’ov. Kým u Ostermeiera každá scénická akcia či herecký detail podporovali a plynulo navrstvovali konzekventne vybudovanú režijnú koncepciu, u Poláka dochádzalo k elementárnej nezrozumitel'nosti interpretačnej kresby postáv. S výnimkou Roberta Rotha v úlohe asesora Bracka sa rozpor medzi vonkajškovou efektnostou a vnútornou nedôslednostou prejavil vo všetkých ostatných hereckých výkonoch. Počnúc Heddou Táne Pauhofovej, ktorá bola skôr oféliovsky krehkým dievčatom, bez presvedčivejšieho obsiahnutia i nihilistických tónov Ibsenovho pôvodného charakteru, až po Moniku Potokárovú. Na jej výkone sa preukázalo, že herečka je ešte primladá na to, aby sama, bez režisérovej pomoci, prenikla do takej závratnej duševnej kontradikcie. Neurčitost’ podtextov sa odzrkadl'ovala najmä v častých bezpríznakových hlasových kadenciách a nevyjasnených motívoch konania. Thea tu pôsobila ako vnútorne dezorientovaná adolescentka, ktorej t’ažko verił také silné osudové zaujatie pre morálnu i vedeckú záchranu zbožňovaného Ejlerta Løvborga (Dano Heriban). Slovami teatrologičky Sone Šimkovej:

${ }^{18}$ KRÉNOVÁ, L'. Myšlenku nezabiješ - I. Slovensko slaví 100 let Československa. In Divadelní noviny, 16. 4. 2018 [online]. [cit. 29. 7. 2020]. Dostupné na internete: https://www.divadelni-noviny.cz/myslenkunezabijes-i-slovensko-slavi-100-let-ceskoslovenska. Preklad z českého jazyka K. M. 


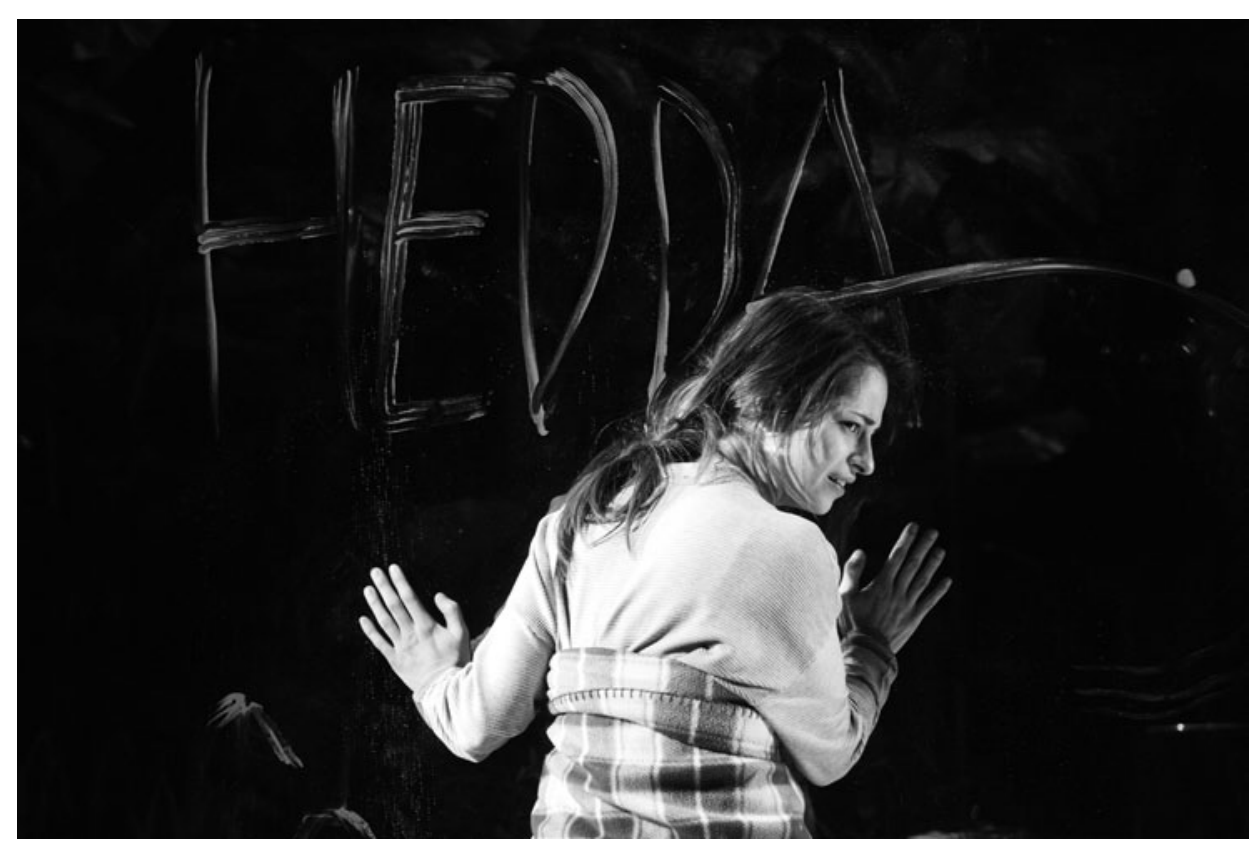

Henrik Ibsen: Hedda Gablerová. Činohra Slovenského národného divadla, premiéra 3. 2. 2018. Réžia Roman Polák. Monika Potokárová (Thea Elvstedová). Foto archív SND. Snímka Robert Tappaert.

„[Thea, pozn. KM] U Ibsena svojou činorodostou, oddanostou predstavuje Heddin protiklad. Talentovaná Monika Potokárová, ktorá nás neprestáva udivovat svojím raketovým vzostupom na doskách SND, dostala prekvapujúce zadanie, hrat' Theu ako škriekajúcu hysteričku a chaotičku. Pri prvom podnete vzbĺkne a vzápätí oblečená vojde do bazéna, kde bezmyšlienkovite prešlapuje, aby sa odreagovala. V nepadnúcom kostýme, ktorý by sa hodil vyššej postave, s privel'kou taškou na pleci, zdá sa, že neplánovane nadobudla podobu smutnej karikatúry naivnej, submisívnej osoby. Nedá sa l'ahko uverit', že by jedným z dôvodov Heddinho dobrovol'ného odchodu bolo, že ju na konci zblížením sa s Tesmanom vyšachovala z hry. ${ }^{" 19}$

Vždy prítomnou hereckou devízou Moniky Potokárovej bola schopnost’ cez klasickú postavu podávat' autentickú výpoved' aj o vlastnej dobe. I v historickom kostýme a vžitej etike a estetike epochy danej hry vyžarovalo z jej kreácií pnutie súčasného života. Markantne to preukázala v posledných dvoch premiérach sezóny 2017/2018. Prvá z nich splácala značný dlh slovenskej kultúry voči uvádzaniu antického divadelného odkazu. Ak aj došlo v našej histórii k naštudovaniu starovekých drám, tak len v máloktorých inscenáciách dokázali tuzemskí tvorcovia dosiahnut tematickú rezonanciu s prebiehajúcim spoločensko-politickým dianím. To sa podarilo Ondrejovi Spišákovi pri naštudovaní Antigony. V mytologickom príbehu o despotickom oligarchovi a jeho vzdorovitej neteri našiel jasnú analógiu s politickou vraždou novinára Jána Kuciaka a jeho snúbenice Martiny Kušnírovej z februára 2018. Interpretačná

${ }^{19}$ ŠIMKOVÁ, S. Kto sa pozerá do zrkadla. In kød, 2018, roč. 12, č. 4, s. 17. 
prepojenost’ s reálnou tragédiou (i ked' v niektorých pasážach inscenácie ilustrovaná až nadbytočne) v porovnaní s pôvodným textom ešte zásadnejšie vyzdvihla konflikt ústrednej politicky i morálne protirečivej dvojice - samolúbeho politika Kreonta (Ján Koleník) a individualistky Antigony.

„Antigona je v SND viac príbehom o tyranii, ako o krehkom hrdinstve.“20, napísala Soňa Jánošová. Napriek tomu, že režisérova interpretácia sústredila pozornost’ väčšmi na analýzu Kreontovho politického i ludského pádu než na príbeh Antigony, Potokárová dokázala aj na obmedzenom priestore vybudovat’ sugestívnu kreáciu. Jej Antigona bola mladá žena plná nekompromisného odhodlania a nezlomnej vnútornej energie zacielenej na povinnost’ pochovat’ nebohého brata. Každá d’alšia odpoved’ na spochybňujúce otázky Ismény (Dominika Kavaschová) bola v jej podaní čoraz rozhorčenejšie vypovedaným protiargumentom, ktorý si nepýtal spätnú väzbu. Antigonu expresívne škicovala ako portrét zahorknutej dievčenskej hrdosti a principiálnosti, modelujúc rolu vo význame prekladu jej mena - hodna svojich predkov. Vedela, prečo chce brata pochovat', a ani na chvílu nezaváhala nad svojím činom. Pritom si v plnom rozsahu uvedomovala možné, až pre život fatálne následky.

Potokárovej vysoko emocionálna, ale zároveň intelektuálne rozhl'adená Antigona nebola zviazaná s predobrazmi zo starogréckych artefaktov. Kostýmom i hereckým výrazom predstavovala súčasnú ženu, prejavom akoby kopírujúcu diváčky sediace v sále. Preto aj pri tlmočení básnického metra nesmerovala svoj prednes k monumentalizujúcemu pátosu, ale k civilnej deklamácii. Rolu v intenciách Spišákovho výkladu doslova odantikizovala. Pri osudovej konfrontácii s Kreontom sa mu odmietala pozriet do očí - a ak, tak jedine s pohl'adom vyjadrujúcim jasnú prevahu jej svedomia nad týmto (pre ňu) nezmyselným súdom. Inak zrak vystatovačne smerovala priamo pred seba, no jasne v ňom zhmotňovala opovrhnutie i dešpekt voči strýkovým vyjadreniam. Jej tvrdošijný vzdor demonštroval jej maximalistickú povahovú podstatu. Oblečená v dlhom čiernom kabáte a šatách lemujúcich štíhle telo asociovala nehybný tmavý monolit, ked' len výnimočne využívala gesto diktované prudšou emóciou. Repliku „Že ma čaká smrt? To viem aj bez teba.“ vyslovila s až pohŕdavou aroganciou, akoby už dopredu počítala s tým, že strýka takouto odpoved’ou súčasne prekvapí i pobúri. Jej mentálnu nezlomnost’ prerušila až informácia o tom, že Kreontova pomsta zastihne aj jej sestru Isménu. To bolo jediné, s čím v tomto pláne nepočítala - že by opät’ niekto siahol na to najvzácnejšie, na jej najbližších. Tu z pevnej kamennej plastiky nečakane vystúpila nestrojená živá bytost'. Milujúca sestra svojej sestry, no súčasne vytrvalá obhajkyňa práv svojho nebohého brata. Preto sa snažila z Ismény vehementným výrazom zmyt’ vinu, ale i so stále prudkým, intenzívnym tónom obraňovat’ božské a nie l’udské (t. j. Kreontove) zákony. Zásadnú myšlienku „Nie pre nenávist', ja pre lásku chcem žit." vypovedala bez akéhokol'vek afektu, skôr odmerane než emotívne, ale s prízvukom na posledných slovách z oboch častí súvetia, oddel’ujúc ich od seba výraznou dramatickou zámlkou. V tom spočívala filozofia jej Antigony. Hrdinka vedela, že konkrétne argumenty sú pri gradujúcej stychomítii s narcistickým politikom zbytočné. Preto mu musela pripomenút svoje životné kré-

${ }^{20}$ JÁNOŠOVÁ, S. Koleník exceluje v úlohe tyrana, ktorý posiela na smrt’ mladých snúbencov. In $S M E$, 19. 4. 2018. [online]. [cit. 29. 7. 2020]. Dostupné na internete: https://kultura.sme.sk/c/20807518/ kolenik-exceluje-v-ulohe-tyrana-ktory-posiela-na-smrt-mladych-snubencov.html. 


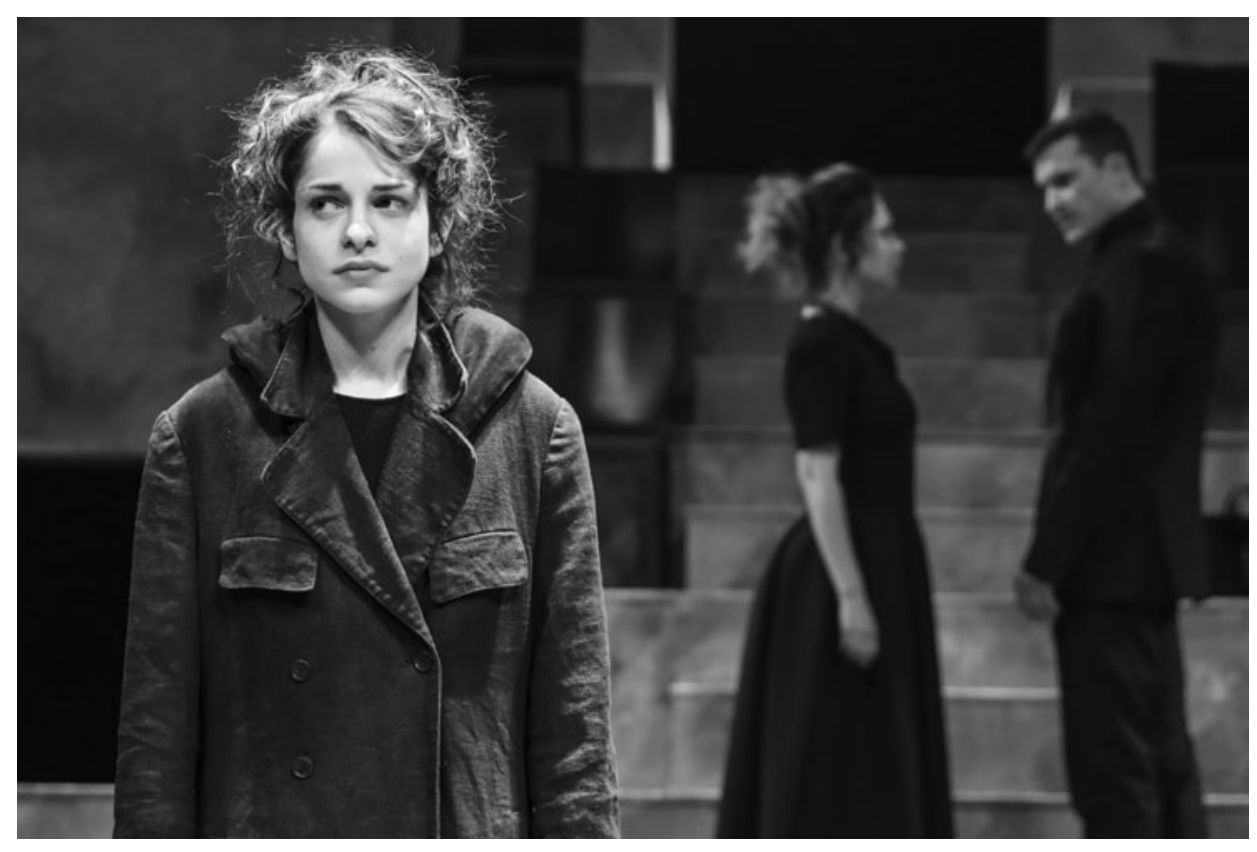

Sofokles: Antigona. Činohra Slovenského národného divadla, premiéra 14. 4. 2018. Réžia Ondrej Spišák. Monika Potokárová (Antigona), Dominika Kavaschová (Isména), Ján Koleník (Kreón). Foto archív SND. Snímka Ctibor Bachratý.

do, ktorým jasne vypovedala, že ak bude strýko v krajine nad’alej vládnut’ doterajším spôsobom, radšej od neho prijme smrt’ než slobodu.

V poslednom monológu už na scéne nestál zosobnený princíp privátnej i spoločenskej zásadovosti, ale mladistvé dievča s vol’ne rozpustenými vlasmi a v bielom negližé. Telo vo fáze najväčšieho l’udského rozpuku, ktorý však nikdy nedosiahne naplnenie. V tomto momente bola Antigona už presvedčená o neodvrátitel'nosti svojej smrti. Preto, ked' si uvedomila blízkost’ podsvetného stretnutia sa s príbuznými, ktorých tak miluje a verí, že aj oni na ňu trpezlivo čakajú, sa napriek tvrdošijnej náture do jej hlasu samovolne dostali i plačlivé vibrácie. No tie onedlho prekryla morálnym pobúrením, ked’ sa do očí publika pýtala, či porušila božie zákony? Rácio opät raz zvít’azilo nad emóciou. To bola hlavná interpretačná pointa Spišákovej - Potokárovej Antigony. Osobné záujmy by mali v každej dobe ustúpit̉ mravnému étosu.

Pomyselným vrcholom sezóny svetovej klasiky v SND, ale i Potokárovej úspešnej cesty $\mathrm{k}$ méte výsostne charakterovej herečky bolo naštudovanie dramatizácie Tolstého románu Vojna a mier v réžii Mariána Amslera. Divadelnú transkripciu Erwina Piscatora, Alfreda Neumanna a Guntrama Prüfera zo štyridsiatych rokov minulého storočia inscenoval v intenciách výpravnej epopeje o intímnej sfére l'udského života na pozadí nekompromisných dejinných udalostí. Tak ako názov románu kladie proti sebe dve obsahovo odstredivé slová, tak i Amslerova režijná koncepcia vychádzala z práce s významovými protikladmi. Jedným z nich bolo aj prepojenie dvoch rozdielnych médií - divadla a filmu, ked’že režisér využil na snímanie paralelných javiskových situácií metódu live cinema. Vo vel'kolepej a technicky náročnej scénickej 
freske dostala Potokárová príležitost’ stvárnit mladú grófku Natašu Rostovovú. A ked’že práve táto postava rozhodla o d’alšom smerovaní herečky, venujeme jej osobitú pozornost'.

V prvej časti inscenácie sa Nataša vyskytovala len minimálne. Počas Rozprávačovho (Robert Roth) predstavovania jednotlivých rol sa uviedla ako neohrabané, rozradostené trinástročné dievčatko s dvomi zapletenými vrkočmi, groteskne vel'kým úsmevom a maximálne roztvorenými žmurkajúcimi očami. Divákom do kamery aj okoloidúcim postavám sa prihovárala vzrušeným prostoduchým hláskom, objímajúc plyšového medvedíka. Nataša totiž práve oslavovala meniny, preto bola štastná, že môže byt’ $\mathrm{v}$ centre pozornosti. Až pokým jej do monológu nevstúpila autoritatívna a emočne odmeraná matka v podaní Ingrid Timkovej. Vtedy Potokárovej Nataša poslušne stíchla. Náhlym poklesom dovtedajšej prepiatej vitality na mizivé minimum jasne poukázala na fakt, že jej matka nemá a ani v nasledujúcom príbehovom dianí nebude mat' pochopenie pre akýkolvvek prejav spontaneity. No sotva nebola nablízku, Nataša opät’ behala po javisku i zákulisí a okázalo sa predvádzala. Potokárová tak jednoduchými znakmi stelesnila detskú infantilnost', neposednost i nedostatočnú schopnost’ v správnej miere vyhodnotit’ svoje správanie v konfrontácii s dospelou spoločnostou.

V druhej časti, ked' sa pozornost' deja sústredila najmä na Natašinu príbehovú líniu, musela herečka prekonat bohatý a v slede inscenácie aj enormne dynamický vývojový oblúk. Od nesmelej dievčenskosti k zrelej ženskosti, od romantizujúcej naivnosti k zložitej l'udskej obsažnosti. Spočiatku sme ju sledovali ako adolescentku po prvýkrát zasiahnutú milostným záchvevom. Potokárovej široký detský úsmev z úvodu inscenácie sa tu zmenil na hanblivý, striedmy - taký, aký káže etiketa, ale tiež automaticky diktuje jej prirodzená hanblivost’ v blízkosti charizmatického Andreja (Ján Koleník). Ked’ však matke a sesternici Soni (Dana Droppová) následne v súkromí hovorila o svojich prepukajúcich citoch, tak to bolo energické dievča prekypujúce životným elánom. Na rozdiel od rozhovoru s adorovaným Andrejom jej gestá už nenachádzali mieru a vzrušené hlasové kadencie nedokázali poslúchat’ svoju nositel'ku. Nataša nevládala kontrolovat’ nespútanost', sama pre seba si hovorila, že ho miluje, vehementne si sugerovala túto idealistickú predstavu a nehladela pritom na preexponovanost' prejavu a ani (nechcenú) bezohl'adnost' voči Soni, ticho plačúcej po jej boku v spoločnej posteli.

Nemenej pôsobivo sa v herečkinom výraze zrkadlili pocity citovej zmätenosti pri prvom stretnutí s budúcim zvodcom - Kuraginom (Ladislav Bédi). Bojazlivo kmitajúce oči, nehybné, pootvorené ústa a zrýchleným dychom sa trepotajúci hrudný kôš, to všetko pojal Potokárovej exteriér do jedného celku v momente konfrontácie pohl'adov medzi ňou a démonicky pôsobiacim oficierom, ktorého sa desila, ale zároveň ho vášnivo hltala očami. V klaustrofobickej zrkadlovej miestnosti, ktorej priestor sa divákom prenášal len cez kamerový záber premietaný na plátno, herečka vyjadrila širokú škálu kontrastov momentálnych Natašiných vnútorných pohnutí. Organicky rozvrhnuté nuansy mimiky v dostatočne zrozumitelnej akcelerácii predstavovali Natašino morálne zdesenie, animálnu žiadostivost̉ i kategorické odmietnutie Kuraginovej ponuky. No krátkym nesústredeným pohl'adom miereným do zeme Potokárová naznačila, že Nataša chce len oklamat’ samú seba. Už o pár sekúnd sa totiž ako zhypnotizovaná vrátila do zrkadlovej predsiene a vášnivo sa vrhla na podmaňujúceho muža, osobnostnými kvalitami tak vzdialeného serióznemu Andrejovi.

V nasledujúcej, iba pár minútovej príbehovej sekvencii, ked’ Soňa s matkou zma- 


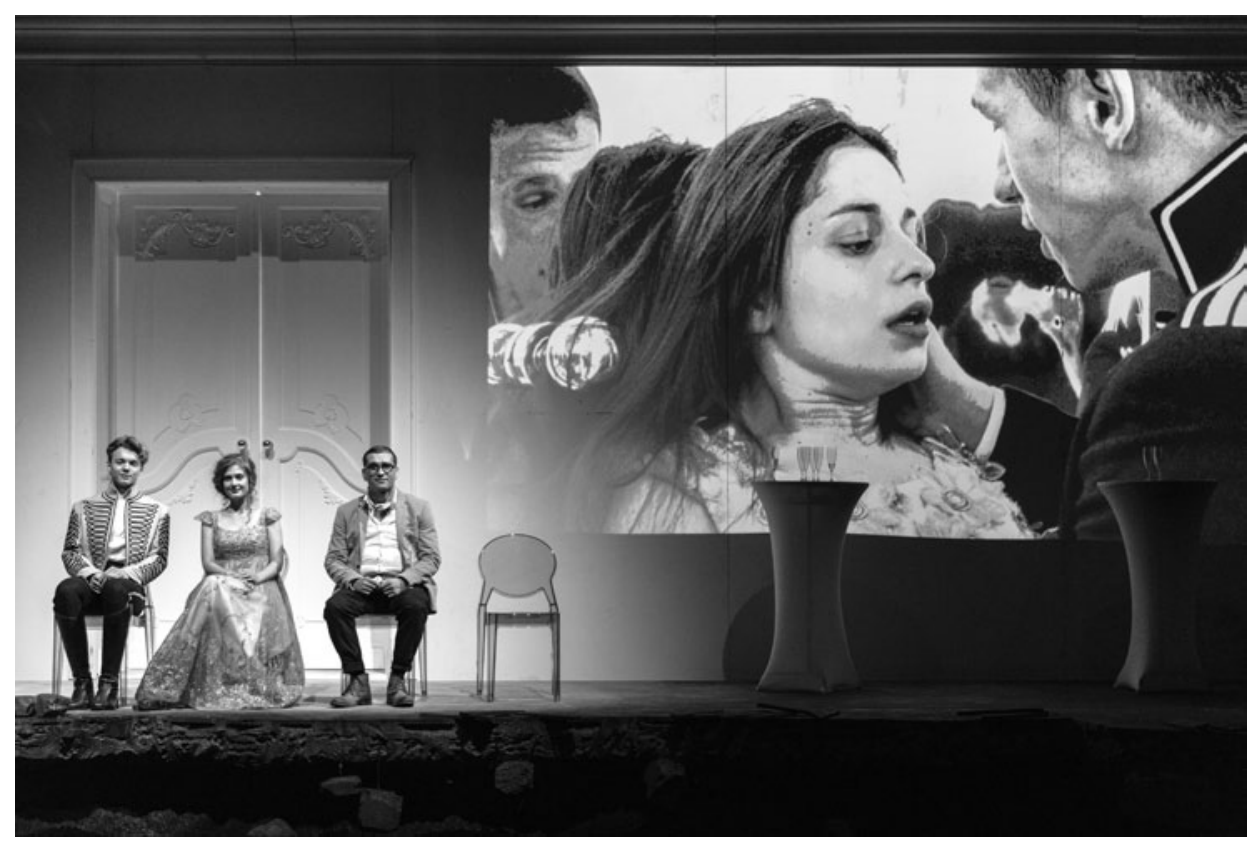

Lev Nikolajevič Tolstoj - Alfred Neumann - Erwin Piscator - Guntram Prüfer: Vojna a mier. Činohra Slovenského národného divadla, premiéra 9. 6. 2018. Réžia Marián Amsler. Jakub Švec (Boris Drubeckij), Kristína Spáčová (Helena Kuraginová), Milan Ondrík (Pierre Bezuchov), Monika Potokárová (Nataša Rostovová), Ladislav Bédi (Anatol Kuragin). Foto archív SND. Snímka Luboš Kotlár.

rili Natašin útek s Kuraginom, sa jej adrenalínové rozochvenie z dievčenského dobrodružstva zmenilo na expresívny vzdorovitý kŕč, ktorý zovrel jej chvejúce sa telo, a drsný rozbesnený hlas nepripúštal kajúcne ospravedlnenie prudkých emócií. Potokárová tu odrazu oponovala všetkému, čo sme predtým videli pri scénach s Andrejom. Nenútenú distingvovanost̉ jej Nataše vystriedal doslova extatický stav. Po ňom nasledovalo kruté vytriezvenie zo zaslepenosti a pochopenie vlastného l'udského zlyhania. Herečke na to stačil prudký dych lomcujúci celým telom a najmä zarazený pohlad, v ktorom sa vd’aka filmovému detailu dal odčítat’ nielen šok zo situácie, ale i náhle uvedomenie si výpočtu neodvratných dôsledkov tohto činu.

Scénickým vrcholom Natašinej dejovej línie bola sólová hra na klavíri na zotmenom javisku. Potokárová vošla na prázdnu scénu len v nočnej košeli, badatelne zlomená až skrehnutá, posadila sa ku klavíru, jemne zatlačila na klávesy a ticho, takmer nebadane začala spievat’ pieseň o vojakovi, ktorý sa ranený vracia z vojny. Interpretácia piesne bola v príkrom protiklade k veselému spevu, ktorým jej trinástročná Nataša zabávala spoločnost' na meninovej oslave na začiatku príbehu. Teraz nedokázala potešit’ ani seba, ani druhých. Vedela, že všetkých sklamala a jediné, čo momentálne dokáže, je vyspovedat’ sa cez rapsodickú pieseň.

Záverečná pasáž inscenácie predstavila Natašu ako prísne racionálnu ženu, ktorej k dosiahnutiu duchovnej dimenzie dospelosti stačilo jediné osudové zlyhanie. Herečka kráčala po scéne pomaly až opatrne, Natašina vnútorná t’ažoba sa pretavila do tažkopádneho pohybu a vnútorného sebaovládania sa. Vonkajškový prejav zredu- 
kovala na minimum, ked' nedokázala ani zdvihnút’ od zeme zmučený pohl'ad. Ako ustala pestrost’ Natašinho života, tak ustala aj Potokárovej vonkajšková dynamika. No nie pulzujúci vnútorný dramatizmus. Herečka v postave presvedčila, že napriek mladému veku (necelý mesiac po premiére dosiahla 25 rokov) dozrela k výsostne charakterovému herectvu.

Sezóna svetovej klasiky priniesla Monike Potokárovej jednoznačný úspech. Herečka v rámci piatich premiér sebavedomo preukázala schopnost’ vystihnút obsah myšlienky (vrátane jej filozofickej hodnoty), cit pre dešifrovanie najhlbších psychických prúdov postáv a zmysel pre vnútornú intenzitu výkonov. Podstatným prvkom jej prejavu bola aj jasná vonkajškovo-výrazová diferenciácia rol, pričom o každej z nich dokázala podat' herecky subjektívne svedectvo. Za vel'mi krátku dobu sa tak stala protagonistkou mladej generácie súboru národného divadla, s potenciálom na ešte širšie rozvinutie charakterizačných i typizačných hereckých dispozícií. ${ }^{21}$

Nasledujúca sezóna 2018/2019, ktorú Činohra SND venovala súčasným inonárodným hrám a zároveň dramatizáciám prozaických predlôh zachytávajúcim podstatné geopolitické zmeny na pozadí prvej svetovej vojny, už nebola pre Moniku Potokárovú natol'ko obohacujúca. Stvárnila tri významovo podstatné úlohy, ale z pohl'adu na inscenačné výsledky až na jednu výnimku nešlo o také produktívne príležitosti ako v predošlej sezóne.

Z dramaturgického okruhu moderných textov dostala možnost’ vytvorit’ jednu zo štyroch rol v intímnej psychologickej dráme Lucy Prebble Vedl'ajšie účinky (26. 1. 2019). V inscenácii Aleny Lelkovej stvárnila Connie, dobrovol'níčku zapojenú do experimentu skúmajúceho účinky nových antidepresív. Herečke sa v autentickej miere, pritom nepredimenzovanými prostriedkami, podarilo postihnút citový potenciál introvertného, záhadného mladého dievčat’a a v autorkou nekonkrétne formulovaných replikách nahmatat intenzívny vnútorný konflikt s vždy jasne zacieleným podtextom. V celkovom kontexte však inscenácia ani herečkin výkon nevybočovali zo štandardnej úrovne.

Po práci na komornej inscenácii čakal Potokárovú pravý opak. Výpravná javisková freska, až dokumentárne ilustrujúca klúčový bod v novodobých ruských dejinách: revolučné obdobie rokov 1917 - 1919 zachytené v autentických spomienkach spisovatel'ky Ale Rachmanovovej, príznačne nazvané Ruské denníky (20. 4. 2019). V dramatizácii a réžii Romana Poláka stvárnila herečka samotnú autorku, empatické dievča pochádzajúce $\mathrm{z}$ vyššej strednej vrstvy, s počiatočne nezištným pohladom na život. Lenže namiesto duchovného a spoločenského rozkvetu, ktorý si tak želá, je svedkyňou násilného rozpadu všetkých dovtedajších životných hodnôt. Kritička a estetička Viera Bartková nazvala Alu „dospievajúcim dievčatom mimoriadnej inteligencie, morálnej vyspelosti, s istou dávkou naivity, charakteristickou pre tento vek. Monika Potokárová má za úlohu vyjadrit spomenutú senzibilitu Ale, výrazne formujúcu jej osobnost' v procese dospievania. V hereckom stvárnení postavy sa jej podarilo zachytit’ nielen emočnú inteligenciu, ale i premenu naivnej intelektuálky s ideálmi a snami

${ }^{21}$ Potokárovej prednostou bola i výborná pamät a herecká operatívnost'. Preto pri výpočte jej úloh treba spomenút pravidelné záskoky a doštudovania úloh za indisponované kolegyne, ktoré vytvorila hned' na niekol'kých scénach (SND, DAB Nitra, GUnaGU, Štúdio 12). Z tých podstatných menujme aspoň Pani Rochestrovú a neskôr samotnú Jane Eyrovú v rovnomennej inscenácii, Elizu v Dobrodružstve pri obžinkoch či Chloe v Arkádii (všetky tri v SND). 
na triezvo uvažujúcu mladú ženu, ktorá, i ked’ otrasená, nestráca vieru v lásku, dobro a súcit." 22

Prvá replika inscenácie, ked’ sa rozradostnená Potokárovej Al’a v prítomnosti chudobnej Máne (Fanny Hostomská) pozerala do zrkadla a s nadšením konštatovala: „Mám len sedemnást’ rokov a celý život pred sebou. Celý život. Aké nekonečné štastie?", bola význačným úvodným akordom inscenácie. Predznamenala osud, ktorý do roka postihne jej najbližších i celé cárstvo. Vtedy Al’a ešte hladela na svoju budúcnost' optimisticky, i ked' Potokárová v tej istej scéne skepticky až chladne skonštatovala: „Som príliš štastná.“ Naivne túžila po starostiach, utrpení, boji, a pritom si neuvedomovala závažnost’ a reálny význam týchto prianí. Prológ inscenácie teda jasne nastavil východiskové murivo k vel'kolepej scénickej klenbe. Lenže to bol jeden z mála výsostne tvárnych hereckých momentov, ktoré dramatizácia i inscenácia herečke poskytli. Stvárňovala síce ústrednú rolu s takmer nepretržitou prítomnostou na javisku, ale jej dramatické určenie sa obmedzovalo len na pozíciu svedkyne príbehových zvratov. Jej funkciou bolo byt „iba“ pozorovatel'kou, ktorá si všetky vnemy a skutočnosti poctivo zapisuje do osobného denníka, ktorý raz poskytne vzácne svedectvo o výraznom historickom medzníku. Preto sa Alino postavenie na scéne posúvalo skôr k polohe pasívneho spoluúčastníka než aktívneho činitel’a. V mnohých dialógoch vyvolávala jej rola podnety $\mathrm{k}$ diskusii, provokovala a iniciovala ku konkretizácii názorových postojov jednotlivých úloh na témy politiky, dejín, spoločenských pomerov. Ale len na vyjadrenie sa "tých druhých“, nie jej postavy.

Potokárová sa tak stretla s nevd’ačnou rolou „nahrávačky“ replík ostatným úlohám. Aktívne sa však ubránila hereckému zatlačeniu do úzadia. Doslova gradovala výrazový register, reakcie dávkovala postupne, vždy hl'adala iný spôsob, ako herecky definovat’ aj emočne obdobné valéry. Dôsledne odlišovala rytmus a kadenciu reči, citlivo odhadovala mieru výrazu a upriamovala pozornost' na nenásilné prechody medzi emočnými polohami, často ústiace do extrémnej obmeny - od intelektuálnej zdržanlivosti až k citovej horlivosti. Aj replikám, ktoré zneli príliš literárne, sa pokúšala vnútorným zainteresovaním vliat životne vierohodné vyznenie. Tým jej kreácia naberala na potrebnej dramatickej tenzii. Al’a ani počas tri a pol hodinovej inscenácie neupadla do monotónnosti, na rozdiel od javiskového celku. Aj v herecky nevd’ačných situáciách, ked' mala vyslovit’ len jednu holú, prípadne málo rozvitú vetu počas niekol'ko minútového dialógu ostatných postáv, nesklzla $\mathrm{k}$ bezobsažnosti či všeobecnosti intonácie. Jej repliky boli vždy jasne emočne adresné, zrozumitelné z hl'adiska techniky i myšlienkového zázemia.

Z hereckého hladiska to teda neboli ani Vedlajšie účinky, ani Ruské denníky, ktoré by ponúkli najmladšej členke súboru podnetnú umeleckú príležitost'. Tá prišla až v závere sezóny. Dve premiéry, ktoré SND paralelne uviedlo v činoherných sálach, Euripidove Bakchantky (25. 5. 2019) a Dürrenmattovi Fyzici (1. 6. 2019), sa síce vymykali z určenej dramaturgickej monotematickosti, ale v oboch prípadoch išlo o najcennejšie inscenačné príspevky sezóny v SND. Dürrenmattovu modelovú hru o duševne chorých pacientoch, ktorí sú v skutočnosti vedeckými géniami, ladil pol’ský režisér Jan Klata do grotesknej štylizácie, synteticky prepájajúcej pohybovú, muzikálnu i vizuálnu stránku. Z filozofickej konverzačnej drámy sa stalo dynamické teatro mundi

${ }^{22}$ BARTKOVÁ, V. Nevyhnutná svedecká výpoved’ v SND. In kød, 2019, roč. 13, č. 6, s. 20. 


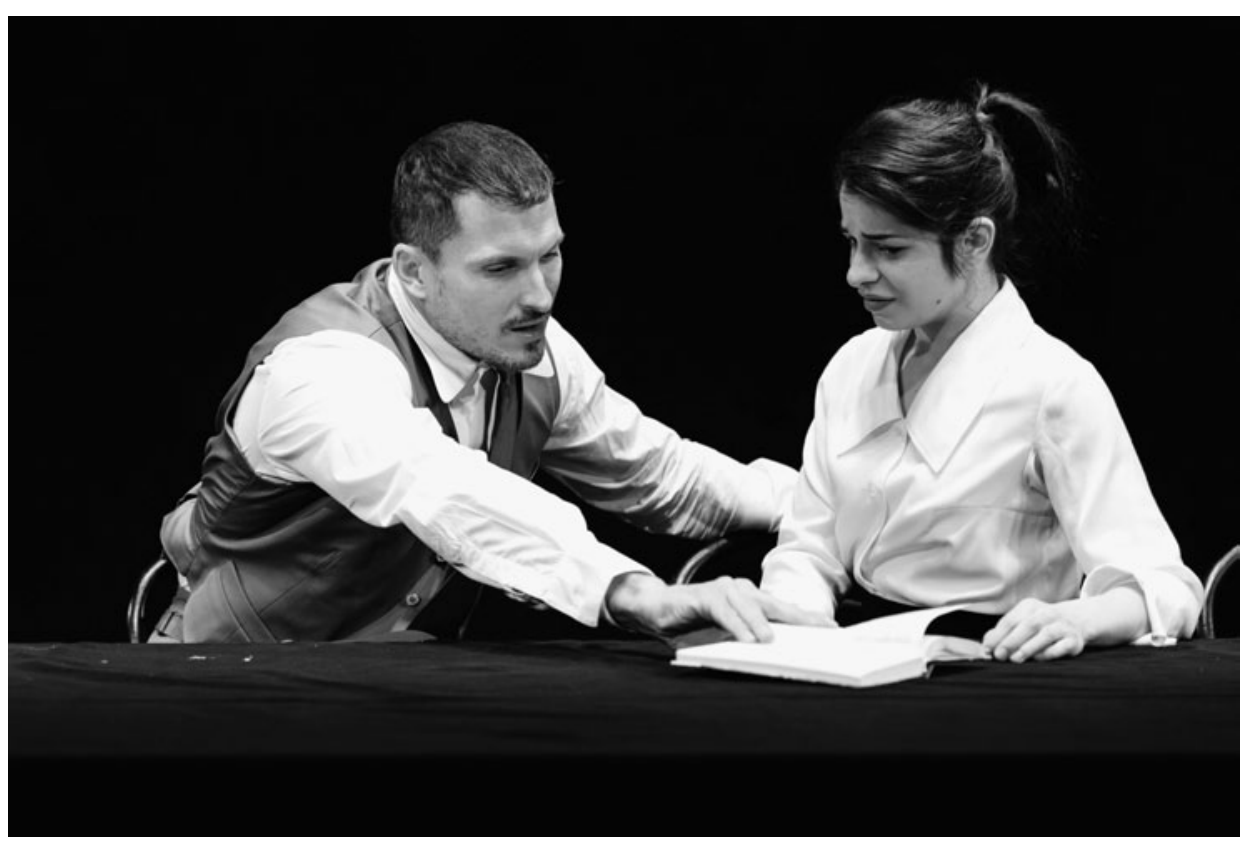

Ala Rachmanovová - Roman Polák: Ruské denníky. Činohra Slovenského národného divadla, premiéra 20. 4. 2019. Réžia Roman Polák. Ján Koleník (Georgij Alexandrovič), Monika Potokárová (Al’a). Foto archív SND. Snímka Robet Tappert.

s výstrednými figúrkami, ktoré využívali výrazový eklektizmus pohybujúci sa v širokom rozpätí, od prvkov klauniády až po kinetickú mechanizáciu. Inscenačný celok však zlyhával na tom, že čast' hereckého obsadenia nedostatočne akceptovala zvolený scénický princíp. Naopak, dominantami Klatovho naštudovania sa stali účinkujúci, ktorí dokázali režisérovu víziu plynulo absorbovat' - Robert Roth (Möbius), Roman Poláčik (Newton), Gabriela Dzuríková (Marta Bollová) a Monika Potokárová (Monika Stettlerová). Tá v malej úlohe obetavej zdravotnej sestry dostala príležitost' využit’ nielen pohybové a pantomimické schopnosti, cit pre žánrový rozptyl, ale najmä zmysel pre komediálne zveličenie. Potokárová totiž disponovala i d’alšou výraznou, hoci režisérmi málo využívanou hereckou črtou - humorom.

Komediálny talent herečky si všimla už na začiatku jej kariéry generačne spriaznená kritička Katarína Cvečková, ked’ konštatovala, že Potokárová „,má výborný zmysel pre pointovanie textu a jej herectvo osciluje medzi civilnou a grotesknou polohou“23. Jej komika skutočne vychádzala zo žoviálnej l’ahkosti, výrazovej bezprostrednosti a nenútenosti. Komediálny odstup dokázala plynulo spojit’ s konkrétnou l'udskou podobou a psychológiou postavy. Herečkin javiskový humor spočíval predovšetkým $\mathrm{v}$ dvoch aspektoch - v konverzačnom nadhl'ade so zmyslom pre výstižné glosovanie textu a v sebaironickom zveličení. Vtedy jej elementárna komediálnost̉ vyplý-

${ }^{23}$ CVEČKOVÁ, K. Rezký Hviezdoslav. In Mloki, 27. 4. 2014. [online]. [cit. 29. 7. 2020]. Dostupné na internete: http://www.mloki.sk/node/176. 
vala z prepiateho pohl'adu vel'kých, neustále hrajúcich očí, karikujúco živých pier a zo špecifického formulovania verbálnej stránky postavy, často s prvkami cielenej deformácie. Vd’aka výrazovej impulzívnosti, schopnosti výstižnej imitácie, citu pre pointu a postihnutie vzácneho balansu medzi vážnostou a komickostou dokázala odl'ahčit situácie aj v dramaticky formovaných inscenáciách, akými boli Zjavenie či Ruské denníky. Pritom spôsob jej javiskového humoru nebol preexponovaný, naopak, prirodzene vychádzal z atmosféry daných okolností.

Potokárovej talent pre tragikomickú osciláciu spočiatku využili najmä Peter Weinciller v Sláva hoiezd ó sláva a Matúš Bachynec vo Všetko za národ, no herečka sa s komediálnymi úlohami stretávala aj neskôr, i ked' menej pravidelne. Vo všetkých prípadoch išlo skôr o menšie, ale vo výsledku zapamätatel'né kreácie. Takou bola neohrabaná nevesta Mášenka v Ostrovského Aj múdry schybí (13. 12. 2014, Mestské divadlo P. O. Hviezdoslava), aj Kurtizána v Shakespearovej Komédii omylov (5. 7. 2017, Letné shakespearovské slávnosti). V druhom menovanom titule sa jej figúrka žiarlivej hetéry stala humorným spestrením inak nezáživnej inscenácie. Režisér Polák totiž herečke nechal všetky repliky zaspievat', takže pre charakterizáciu úlohy mohla využit’ svoju naturálnu muzikálnost', tentoraz s príklonom k operetnej paródii. Ústrednými činohernými prvkami jej prejavu sa tu stali pohotová gestická teatralita a cielené hyperbolizovanie vlastnej vizáže: pri erupcii emócií dôrazne exponovala pohl'ad, mraštila tvár či našpul'ovala i tak prirodzene plné pery. $\mathrm{K}$ dovŕšeniu grotesknosti výrazu jej poslúžila aj fyzická podoba postavy. Po javisku cupitala drobnými, ale zato energickými krokmi v úzkej sukni s nadrozmerne zväčšenými bokmi.

Klatovi Fyzici znamenali pre Potokárovú podobnú malú úlohu s vel'kými hereckými možnostami. Jediný dialóg sestry Moniky, zamilovanej do pacienta psychiatrickej liečebne Möbia (Robert Roth), pod ktorého krycím menom sa ukrýva génius svetového formátu, situoval režisér na stoličky opreté o stenu scény. Obaja herci na nich sedeli vo vystretých pózach, s pohl'admi upretými do hl'adiska, bez akejkol'vek dotykovej konfrontácie. Ich register vyjadrovacích možností sa teda zúžil len na hlas a mimiku, ked' detaily ich tvárí približovala kamera na trojicu plátien visiacich nad javiskom (jedno pre Moniku, druhé pre Möbia, tretie pre spoločný záber). Klata viedol Potokárovú k podobe oduševnene exaltovaného dievčata, ktorého reakcie sú motivované výbušnou vnútornou aktivitou a navonok stvárnené v organicky pôsobiacich dynamických prechodoch. Základné štylizačné ladenie Potokárovej výkonu vystihla kritička Martina Ulmanová: „(...) rozhovor Möbiusa a zalúbenej sestry Moniky je štylizovaný ako bábkové divadlo - ona, vd’aka naondulovanému blond účesu, kriklavému mejkapu aj výrazu naivky vyzerajúca ako predmet lacných sexuálnych fantázií, meravo sedí vedl'a svojho idolu, obaja pozerajú do publika. Nemajú spolu nijaký fyzický kontakt, pôsobia ako dvaja bezradní recitátori. Potokárovej sestrička gúl'a očami, plače staby postava z l’udovej sentimentálnej hry. Ked' hovorí o boji, ktorý budú musiet’ s Möbiusom podstúpit’ na spoločnej ceste ,cez výsmech a posmievanie, cez nevieru a pochybnosti', zmení sa na karikatúru bojovníčky - reve, usilovne napína bicepsy. Nasleduje tanec dvojice, na ktorého konci Möbius sestričku zaškrtí - vytrčené zadky a prehnané gestá opät pripomínajú skôr bábky ako živých l’udí. ${ }^{24}$

${ }^{24}$ ULMANOVÁ, M. Fyzici bez jadra. In kød, 2019, roč. 13, č. 8, s. 12 - 13. 


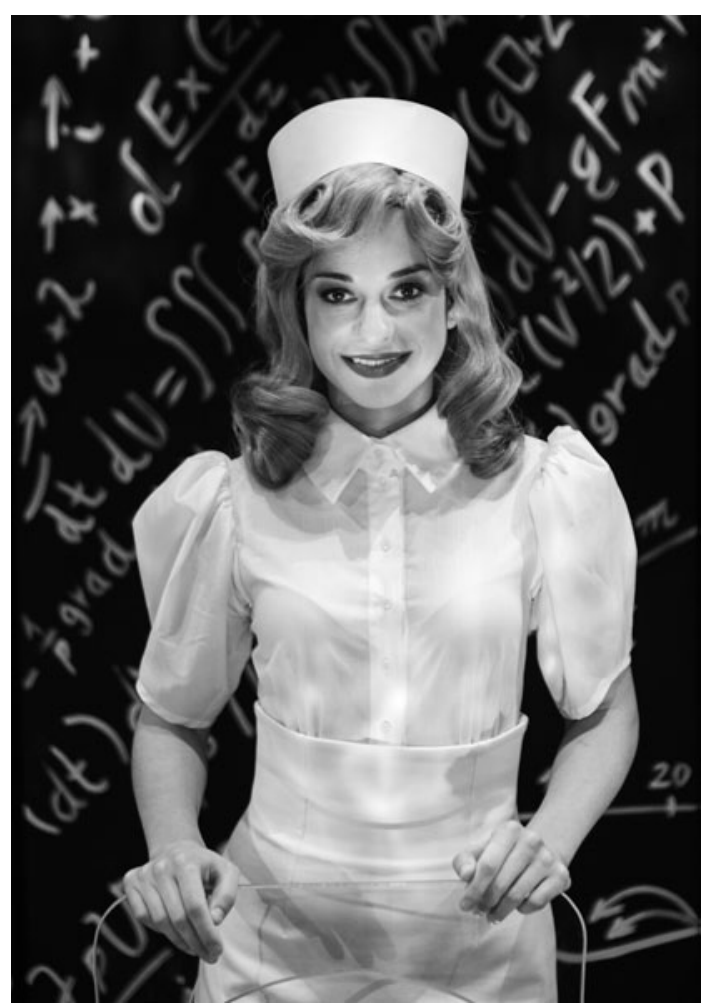

Friedrich Dürrenmatt: Fyzici. Činohra Slovenského národného divadla, premiéra 1. 6. 2019. Réžia Jan Klata. Monika Potokárová (Monika Stettlerová). Foto archív SND. Snímka Radovan Dranga.

Potokárovej pestrá herecká kaskáda (inak jej „prepínanie“ polôh a emočných dížok na takom obmedzenom priestore ani nemožno nazvat') mala jasný interpretačný zámer. Herečka programovo zveličovala, dramatizovala mimiku, prudko striedala rytmus reči, fanaticky zatajovala dych a následne zo seba horlivo vypúštala zaslepenostou formované slová, bola plná napätia a vzrušenia zo svojho plánu spoločného života s adorovaným fyzikom. Akoby s hedonistickou rozkošou parodovala bezduché romantické hrdinky z lacných filmov, ktorých predstavitel'ky sa chcú na minimálnom priestore čo najviac herecky prejavit’ a prezentovat’ maximum „talentu“. To všetko Potokárová dokázala sklbit do účinnej hyperbolickej skratky, kde opätovne preukázala cit pre mieru i príklon k štylizovanému divadelnému jazyku. A hoci rola Moniky bola v porovnaní s Connie a Alou Rachmanovovou v priestorovom úzadí, pre Potokárovú znamenala jednoznačný progres umeleckých síl.

O schopnosti hereckej adaptability v poetike, ktorá je syntézou pohybového výrazu so silným činoherným zázemím, mala Potokárová šancu presvedčit’ ešte pred Fyzikmi. Medzi premiérami Ruských denníkov kotviacich v psychologicko-realistických konvenciách a eklektickým mumrajom Fyzikov, ktorý Miro Zwiefelhofer výstižne nazval nukleárnym jukeboxom Jana Klatu², totiž hostovala v inscenácii

${ }^{25}$ ZWIEFELHOFER, M. Nukleárny jukebox Jana Klatu v SND. In Monitoring divadiel, 21. 1. 2020. [online]. [cit. 29. 7. 2020]. Dostupné na internete: https://www.monitoringdivadiel.sk/recenzie/recenzia/nuklearny-jukebox-jana-klatu-v-snd/. 


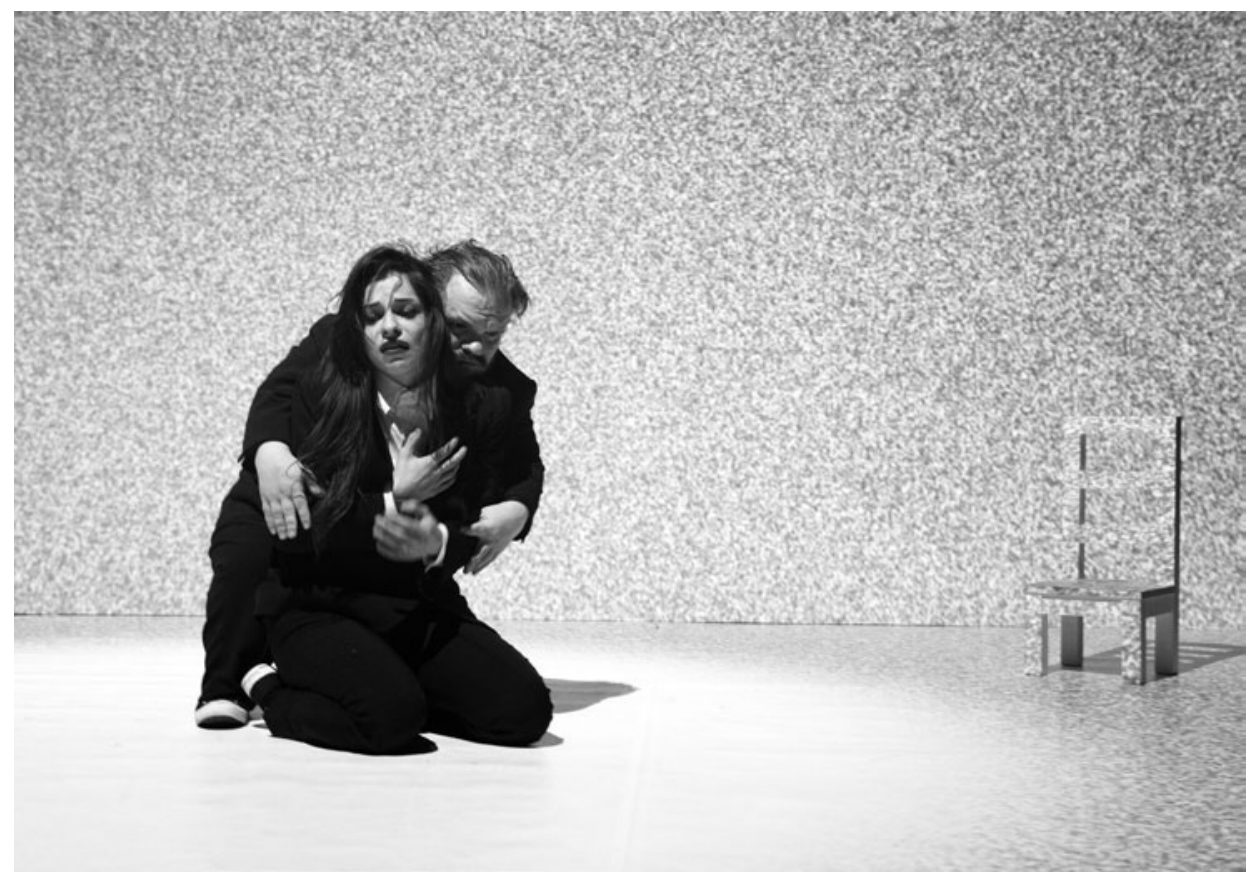

Peter Lomnický: Jób. Debris Company, premiéra 27. 5. 2019. Réžia Jozef Vlk. Monika Potokárová, Michal Noga. Foto archív Debris Company. Snímka Katarína Križanovičová.

zoskupenia Debris Company Jób (27. 4. 2019). V intertextuálnej koláži Petra Lomnického, v réžii Jozefa Vlka a choreografii Stanislavy Vlčekovej, stvárnila komplikovanú a na filozoficko-existenčné postuláty bohatú rolu Ruth. Podobne ako vo Fyzikoch, aj tu musela prudko striedat' extrémne emočné polohy, z hlasového pianissima prechádzat’ do fortissima a spät', marginálie vyslovovat’ s dramatizujúcou zaujatostou, epické dišputy zase tónom bežnej konverzácie. Činoherné konanie následne prerušovala dôrazným gestom, prípadne verbalitu doslova suplovala alebo kontrovala náročnou pohybovou štylizáciou. V mysterióznej a príbehovo fragmentárnej inscenácii sa nemohla opriet’ o príbehovú kauzalitu príznačnú pre majoritnú dramaturgiu titulov SND. Pre Potokárovú to však nebolo prekážkou. Dokázala naplnit maximálne požiadavky na syntetické herectvo a využívanie prudkého strihu, balansovat' medzi umením odstupu a psychologickej skratky, zvládnut ostré prechody medzi verbálnym, vokálnym a pohybovým prejavom. Výrečným zameraním sa na psychologicko-intelektuálne podhubie textu vedela dodat’ abstraktným replikám konkrétny význam. V sugestívnej vizuálno-pohybovo-hudobnej inscenácii navyše, slovami recenzentky Martiny Mašlárovej, „dokázala výborne pohybom pretlmočit vnútornú rozorvanost’ ženy (...) v impulzívnych a kŕčovitých tanečných výstupoch. Zároveň gestami podčiarkovala aj náladu jednotlivých skladieb, ktoré taktiež vel’mi čisto a podmanivo odspievala, vrátane najzložitejších, až operných partov. (...) Sledovat’ herečku opät’ v inej pozícii, v ktorej sa nemusí prevtel'ovat’ do postavy a naopak, hlasovou štylizáciou a abstraktným pohybom vytvára nuansy 
psychologických poryvov, uštipačnou iróniou vyvracia a zároveň podporuje pochmúrnost̉ inscenácie, rozrušuje vizuálne kompaktné a hladké obrazy grimasami a hrozivou dikciou, prináša zriedka zažívaný pôžitok. “26

\section{Predčasný epilóg}

Predposledná premiéra v herečkinom živote a zároveň jej posledná v SND sa akoby symbolicky odohrala na javisku, kde pred pár rokmi začala výraznejšie upozorňovat’ na svoju umeleckú individualitu - v Modrom salóne SND. V rámci spolupráce deviatich európskych divadiel naštudovala pod režijným vedením Júlie Rázusovej slovenský príspevok do tejto medzinárodnej koprodukcie, inscenáciu hry Alexandry Salmely Cudzô (11. 10. 2019), ktorá vznikla na základe ankety uskutočnenej medzi respondentmi vo veku 11 až 17 rokov. Autorka v ňom formou koláže autentických výrokov sprostredkovala generačný pohl'ad na témy strachu, identity či vízie budúcnosti. Cielene eklektický, štýlovo zlomkovitý text a následne aj jeho inscenácia tak až s antropologickou dôkladnostou odrážali impresie slovenských teenagerov. To na hereckých predstavitel'ov - Moniku Potokárovú a Braňa Mosného - kládlo značné nároky: v okamžitej bezprostrednosti striedat’ psychologický poryv so štylizovanou persiflážou, priamu reč menit’ na rozprávanie v tretej osobe, realistický strih kombinovat’ s prvkami bábkarskej techniky, tieňového divadla či práce s live cinema. Potokárová tu opätovne podporila tézu, že aj napriek pribúdajúcim rolám na domácej scéne sa nevžíva s jej konzervatívnym hereckým slohom. Práve naopak. Do úryvkovito vystavanej úlohy dokázala vložit’ maximum tvorivej vynaliezavosti. Na akcentovanie daného javiskového momentu jej stačilo málo: jasný vetný prízvuk, pohl’ad definujúci emóciu, dôsledné rytmizovanie textu, uvedomelá a precízna práca s rekvizitou či parodická interpretácia bezduchých instagramových influenceriek pri songu My Favorite Things z muzikálu The Sound of Music. Opät' to bol vel'ký výkon na malej ploche. Došlo však len k premiére a prvej repríze.

Úplne poslednou Potokárovej premiérou, uvedenou presne mesiac pred jej tragickým odchodom, bola Žiačka v Ionescovej absurdite Lekcia (25. 10. 2019) v Divadle Aréna. Inscenácia Rastislava Balleka priniesla najmä hereckú exhibíciu Roberta Rotha ako predstavitel'a fanatického Profesora. No Potokárová dokázala i na menšom priestore herecky rozkreslit’ svoju rolu do farbistej kreácie, ked' skombinovala prepiato aktívnu študentku okázalo prežúvajúcu žuvačku a chodiacu v pubertálnej ružovej bundičke, ktorá uverila vlastnej póze záujmu o vyššie vzdelanie, s nekultivovaným dievčatom výrazne nedostatočného intelektu. Väčšinu času inscenácie sedela medzi divákmi v hl'adisku a so všetkou vážnostou, zaujatím, prípadne infantilným pobavením reagovala na Profesorovu krkolomnú výučbu. Jej Žiačku charakterizovala neustála mikroetudová hyperaktivita a nepredstierané naivné očarenie z prednášanej látky. Slovami Martiny Ulmanovej „bola (...) ako otvorená kniha, pôsobila dievčensky nevinne a jednoducho, dokonca aj vtedy, ked’ z nej začali vychádzat' na povrch ionescovsky čudné veci (pretože nerozumie jednoduchej aritmetike, naučila sa naspamät’ všetky možné výsledky všetkých možných kombinácií násobe-

${ }^{26}$ MAŠLÁROVÁ, M. Jóbovka o živote človeka. In kød, 2019, roč. 13, č. 7, s. 13 - 14. 
nia). Potokárovej Žiačka bola čudná bezprostredným, radostným a bezstarostným spôsobom. ${ }^{\text {27 }}$

Kým v Antigone, Vojne a mieri či Ruských denníkoch vychádzala Potokárová z metódy zžitia sa s osudom postavy, kde sa jej nenútený prejav opieral o bohatstvo civilných hlasových, gestických a mimických detailov, ktoré jej umožnili divákom účinne sprostredkovat' tie najzásadnejšie vnútorné stavy a premeny charakteru, tak Fyzici, Jób, Cudzô a Lekcia od nej vyžadovali presný opak. V antiiluzívnom inscenačnom tvare (v zmysle psychologicky nehierarchizovaného výberu výrazových prostriedkov) musela cez lakonicky pôsobiaci prejav vyjadrit komplexný substrát postavy. Dokázala tak pluralitu svojho talentu a rýchlo dozrievajúce herectvo, pripravené na d’alšie náročné výzvy. Krátko po premiére Lekcie začala v SND skúšat’ postavu Jenůfy v inscenácii Preissovej dedinskej tragédie Její pastorkyňa. Po nej mala nasledovat folklórne ladená cigánka Dora v Hollého Kubovi a I. herečka v dráme Romana Poláka o živote emblematického filmára - Scény zo života (Ingmara Bergmana). K naštudovaniam týchto úloh už nedošlo.

\section{Miesto v generácii}

Herectvo Moniky Potokárovej, podobne ako herectvo jej rovesníkov, je tažké priradit’ k vyhranenej umeleckej metóde. Množstvo režijných osobností a poetík dramatikov, s ktorými sa dnešná začínajúca generácia stretáva, ich núti k enormnej plastickosti a prispôsobivosti. Čerpajú pritom zo základných a dodnes aktuálnych postupov Konstantina Sergejeviča Stanislavského, Vsevoloda Emilieviča Mejerchol'da či Bertolta Brechta, vd’aka čomu v ich herectve vzniká syntéza, ktorá dokáže viest’ ich prejav tak k nenásilnosti až všednosti výrazu (bez ilustratívneho stotožnenia sa s postavou, pod ktorou mizne osobnost’ predstavitela), ako aj k demonštratívnemu emočnému odstupu. A to bez toho, aby ich prostriedky stratili na sile pôsobivosti. Svoju poetiku zakladajú na pestrom pohybe medzi prirodzeným a štylizovaným, čím táto generácia vytvára zásadný medzník vo vývoji slovenského herectva.

Aj Potokárová disponovala touto tvárnostou, teoretické základy premieňala v praxi do bohato stupňovaných výkonov. Výnimočnost’ jej hereckého prejavu však spočívala v zásadnej oponentúre k vel'kej časti rovesníkov (ale i kolegov z mierne staršej generácie) - nepodliehala všadeprítomnej hereckej laxnosti a univerzálnosti výrazu. Jej herectvo obsahovalo nezvyčajnú intelektuálnu i emočnú híbku, horizontálu i vertikálu. Bola schopná hereckej premeny, výstižnej vonkajškovej i vnútornej charakterizácie úloh, vládla kultivovanou javiskovou rečou s dôslednou dikciou a špecifickou modulačnou plasticitou. Aj toto všetko z nej vytvorilo jeden z najpozoruhodnejších zjavov nielen jej generácie, ale slovenského herectva vôbec.

${ }^{27}$ ULMANOVÁ, M. Posledná Lekcia. In Monitoring divadiel, 14. 1. 2020. [online]. [cit. 29. 7. 2020]. Dostupné na internete: https://www.monitoringdivadiel.sk/recenzie/recenzia/posledna-lekcia/. 


\section{THE PERSONALITY OF THE ACTRESS MONIKA POTOKÁROVÁ}

\section{Karol MIŠOVIC}

During her short professional career, Monika Potokárová (1992 - 2019) became a protagonist of the young generation of actors at the Drama Company of the Slovak National Theatre. She has rendered over forty diverse roles in the productions directed by acclaimed Slovak and international directors. She was a genuine protagonist of tragic heroines of classical repertoires, and her versatile talent enabled her to create characters defying psychological and realistic canons of Slovak drama acting. The study highlights the most significant roles of the young actress and it endeavours to define her pliability, flexibility, and the uniqueness of her artistic personality.

Príspevok je súčastou riešenia projektu VEGA č. 2/0173/19 Cesta slovenského divadla od uzavretej k otvorenej spoločnosti (udalosti, osobnosti, inscenácie).

\section{LITERATÚRA}

BARTKOVÁ, Viera. Nevyhnutná svedecká výpoved’ v SND. In kød, 2019, roč. 13, č. 6, s. 19 - 25. ISSN 1337-1800.

CVEČKOVÁ, Katarína. Rezký Hviezdoslav. In Mloki, 27. 4. 2014. [online]. [cit. 29. 7. 2020]. Dostupné na internete: http://www.mloki.sk/node/176. ISSN 1339-8113.

CVEČKOVÁ, Katarína. Nenaplnené túžby troch sestier a jednej inscenácie. In Monitoring divadiel, 26. 4. 2016. [online]. [cit. 29. 7. 2020]. Dostupné na internete: https://www.monitoringdivadiel. sk/recenzie/recenzia/nenaplnene-tuzby-troch-sestier-a-jednej-inscenacie/. ISSN 2454-0129.

HAGEMANN, Carl. Herecké umění a herci. Cit. podla RUTTE, Miroslav. O umění hereckém : Kestetice a psychologii divadelní a filmové tvorby. Praha : Jos. R. Vilímek, 1946. $244 \mathrm{~s}$.

JÁNOŠOVA, Soňa. Modlitba pre Moniku, kabaret pre normalizáciu. In kød, 2018, roč. 12, č. 2, s. 50. ISSN 1337-1800.

JÁNOŠOVA, Soňa. Koleník exceluje v úlohe tyrana, ktorý posiela na smrt̉ mladých snúbencov. In $S M E, 19.4$. 2018. [online]. [cit. 29. 7. 2020]. Dostupné na internete: https://kultura.sme. sk/c/20807518/kolenik-exceluje-v-ulohe-tyrana-ktory-posiela-na-smrt-mladych-snubencov. html. ISSN (online) 1335-4418.

KRÉNOVÁ, Lubica. Myšlenku nezabiješ - I Slovensko slaví 100 let Československa. In Divadelní noviny, 16. 4. 2018. [online]. [cit. 29. 7. 2020]. Dostupné na internete: https://www.divadelni-noviny.cz/myslenku-nezabijes-i-slovensko-slavi-100-let-ceskoslovenska. ISSN 1210-471X.

MAŠLÁROVÁ, Martina. Národ, to znie hlúpo. In Monitoring divadiel, 17. 4. 2016. [online]. [cit. 29. 7. 2020]. Dostupné na internete:: https://www.monitoringdivadiel.sk/recenzie/recenzia/ narod-to-znie-hlupo/. ISSN 2454-0129.

MAŠLÁROVÁ, Martina. Plávat’ a neutopit’ sa v špine Babylonských riek. In kød, 2016, roč. 10, č. 4 , s. $18-23$. ISSN 1337-1800.

MAŠLÁROVÁ, Martina. Jóbovka o živote človeka. In kød, 2019, roč. 13, č. 7, s. 11 - 14. ISSN 1337-1800.

RUTTE, Miroslav. O umění hereckém : Kestetice a psychologii divadelní a filmové tvorby. Praha : Jos. R. Vilímek, 1946. $413 \mathrm{~s}$.

SMOLKOVÁ, Soňa. J. Brehy babylonských riek sú tmavé a neveselé. In Pravda, 2016, roč. 26, č. 26, s. 32, 2. 2. 2016. ISSN 1335-4050. 
SMOLKOVÁ, Soňa J. Poetické prekvapenie v Modrom salóne. In Pravda, 2016, roč. 26, č. 220, s. 33, 22. 9. 2016. ISSN 1335-4050.

SMOLKOVÁ, Soňa J. Zo života l'udstva je polovičný zážitok. In Pravda, 2016, roč. 26, č. 258, s. 31, 7. 11. 2016. ISSN 1335-4050.

ŠIMKOVÁ, Soňa. Kto sa pozerá do zrkadla. In kød, 2018, roč. 12, č. 4, s. 10 - 17. ISSN 1337-1800.

ŠMATLÁKOVÁ, Lucia. Ako mocných vystrašila jedna (ne)obyčajná pieseň. In Mloki, 30. 12. 2017. [online]. [cit. 29. 7. 2020]. Dostupné na internete: https://www.mloki.sk/node/819\#/0. ISSN 1339-8113.

PAŠUTHOVÁ, Zdenka. Oslava Hviezd(oslava). In Katolícke noviny, 2013, roč. 128, č. 18, s. 21, 5. 5. 2013. ISSN 1336-2399.

ULMANOVÁ, Martina. Fyzici bez jadra. In kød, 2019, roč. 13, č. 8, s. 10 - 14. ISSN 1337-1800.

ULMANOVÁ, Martina. Posledná Lekcia. In Monitoring divadiel, 14. 1. 2020. [online]. [cit. 29. 7. 2020]. Dostupné na internete: https://www.monitoringdivadiel.sk/recenzie/recenzia/posledna-lekcia/. ISSN 2454-0129.

ZWIEFELHOFER, Miroslav. Príliš plytké mystérium. In kød, 2017, roč. 11, č. 10, s. 12 - 18. ISSN 1337-1800.

ZWIEFELHOFER, Miroslav. Nukleárny jukebox Jana Klatu v SND. In Monitoring divadiel, 21. 1. 2020. [online]. [cit. 29. 7. 2020]. ISSN 2454-0129. Dostupné na internete: https://www.monitoringdivadiel.sk/recenzie/recenzia/nuklearny-jukebox-jana-klatu-v-snd/. ISSN 2454-0129.

Karol Mišovic

Ústav divadelnej a filmovej vedy CVU SAV

Dúbravská cesta 9

84104 Bratislava

e-mail: karol.misovic@savba.sk 


\section{Súpis divadelných postáv Moniky Potokárovej}

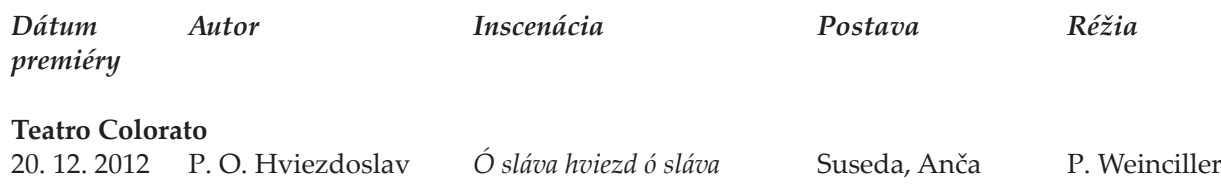

Slovenské národné divadlo

$\begin{array}{lllll}\text { 26. } 2.2013 & \text { D. Hevier } & \text { Večer rockovej poézie } & \text { Účinkujúca } & \text { D. Hevier } \\ \text { 22. } 10.2013 & \text { D. Hevier } & \text { Blake si black } & \text { Účinkujúca } & \text { D. Hevier } \\ \text { 2. } 4.2014 & \text { J. Littell } & \text { Láskavé bohyne } & \text { Zbor } & \text { M. Vajdička }\end{array}$

Divadlo Ludus
13. 10.2014
I. Lausund
Hysterikon
Účinkujúca
R. Maroš

Mestské divadlo Pavla Országha Hviezdoslava
13. 12. 2014
A. N. Ostrovskij
Aj múdry schybí
Mášenka
V. Schulczová
Teatro Colorato
17. 12. 2014 K. Wojtyla Lúče otcovstva $\quad$ Monika $\quad$ P. Weinciller

Vysoká škola múzických umení
14. 1. 2015
A. P. Čechov
Tri sestry
Máša
J. Mudrák

Slovenské národné divadlo
31. 1. 2015
F. Švantner
Nevesta hôl'
Dievča
R. Polák

Vysoká škola múzických umení
21. 4. 2015
B. S. Timrava

Všetko za národ

Hana Čepčínska

M. Bachynec

Slovenské národné divadlo
9. 6. 2015
D. Majling

Labyrinty a raje Jána Amosa

Kristína

O. Spišák

Vysoká škola múzických umení
26. 11. 2015
F. Langer
Periféria
Anna
M. Bachynec

Slovenské národné divadlo
30. 1.2016
P. Pištánek
Rivers of Babylon
Lenka
D. de Brea
2. 4.2016
Z. Dzurindová a kol. Morálka 2000+
Jana
A. Lelková

Vysoká škola múzických umení
16. 5. 2016
M. Gavran
Je svätá
Šua
M. Bachynec

Slovenské národné divadlo
7. 6. 2016 V. Klimáček
Sissi
29.6. 2016 M. Haugová a kol.
Branné coičenie
Mary Vetserová
E. Novák
5. 11.2016
P. Weiss
Zo života l'udstva
Účinkujúca
K. Šafaříková
a kol.
Monika
D. Mustafić

\section{Divadlo Aréna}
10. 11. 2016
M. Houellebecq
Podvolenie
Myriam
M. Amsler 
Vysoká škola múzických umení

21. 11. 2016 W. Allen

Slovenské národné divadlo

7. 1. $2017 \quad$ P. Esterházy

25. 3. 2017 B. Studlar

3. 6. 2017 R. Olekšák,

V. Schulczová

Letné shakespearovské slávnosti

5. 7. 2017 W. Shakespeare

Slovenské národné divadlo

4. 11. 2017 V. Klimáček

7. 12. 2017 M. Bachynec

3. 2. 2018 H. Ibsen

14. 4. 2018 Sofokles

9. 6. 2018 L. N. Tolstoj a kol.

26. 1.2019

L. Prebble

20. 4. 2019

A. Rachmanovová

Debris Company

27. 5. 2019

P. Lomnický

Jób

Mercedes Benz

Túžba po nepriatelovi

Rodáci

Komédia omylov

Kurtizána

R. Polák

Zjavenie (Hrobárova dcéra)

Kabaret normalizácia

Hedda Gablerová

Antigona

Vojna a mier

Vedlajšie účinky

Ruské denníky
R. Polák

Druhá milenka

R. Polák

Dievča

Dominika

J. Luterán

T. Köhler
Barbara, Julie

Dcéra

V. Serre

Marta Kubišová

Thea Elvstedová

R. Polák

Antigona

O. Spišák

Nataša Rostovová

M. Amsler

Connie

A. Lelková

Ala

R. Polák

Slovenské národné divadlo
1. 6.2019
F. Dürrenmatt
Fyzici
11. 10. 2019
A. Salmela
Cudzô
Monika Stettlerová J. Klata
36
J. Rázusová
Divadlo Aréna
25. 10. 2019
E. Ionesco
Lekcia
Žiačka, Slúžka
R. Ballek

M. Bachynec

Postavy stvárnené v záskokoch a doštudovaniach (bez presného dátumu vystúpenia)

Divadlo Andreja Bagara v Nitre
G. Hauptmann
Potkany
Walburga
R. Polák

Divadlo GUnaGU
V. Klimáček
In Da House
Zuzana
K. Vosátko

Štúdio 12
J. Juráňová
Misky strieborné,
Braxatorisová
A. Lelková
G. Orwell
nádoby výborné
Princípy Newspeaku
Júlia
R. Ballek

Slovenské národné divadlo

Ch. Brontëová a kol. Jane Eyrová neskôr Jane Eyrová

T. Stoppard

J. Palárik
Arkádia

Dobrodružstvo pri obžinkoch
Rochestrová

M. Amsler

Chloe Coverlyová R. Polák

Elisa Hrabovská J. Nvota 